\title{
Zooming into the Dark Side of Human Annexin-S100 Complexes: Dynamic Alliance of Flexible Partners
}

\author{
Judith Weisz ${ }^{1}$ and Vladimir N. Uversky ${ }^{2,3, *(1)}$ \\ 1 Departments of Gynecology and Pathology, Pennsylvania State University College of Medicine, \\ Hershey, PA 17033, USA; jxw7@psu.edu \\ 2 Institute for Biological Instrumentation of the Russian Academy of Sciences, Federal Research Center \\ "Pushchino Scientific Center for Biological Research of the Russian Academy of Sciences", \\ Pushchino, 142290 Moscow, Russia \\ 3 Department of Molecular Medicine and USF Health Byrd Alzheimer's Research Institute, Morsani College \\ of Medicine, University of South Florida, Tampa, FL 33612, USA \\ * Correspondence: vuversky@usf.edu; Tel.: +1-813-974-5816 (ext. 123); Fax: +1-813-974-7357
}

Received: 22 July 2020; Accepted: 13 August 2020; Published: 16 August 2020

\begin{abstract}
Annexins and S100 proteins form two large families of $\mathrm{Ca}^{2+}$-binding proteins. They are quite different both structurally and functionally, with S100 proteins being small (10-12 kDa) acidic regulatory proteins from the EF-hand superfamily of $\mathrm{Ca}^{2+}$-binding proteins, and with annexins being at least three-fold larger (329 \pm 12 versus $98 \pm 7$ residues) and using non-EF-hand-based mechanism for calcium binding. Members of both families have multiple biological roles, being able to bind to a large cohort of partners and possessing a multitude of functions. Furthermore, annexins and S100 proteins can interact with each other in either a $\mathrm{Ca}^{2+}$-dependent or $\mathrm{Ca}^{2+}$-independent manner, forming functional annexin-S100 complexes. Such functional polymorphism and binding indiscrimination are rather unexpected, since structural information is available for many annexins and S100 proteins, which therefore are considered as ordered proteins that should follow the classical "one protein-one structure-one function" model. On the other hand, the ability to be engaged in a wide range of interactions with multiple, often unrelated, binding partners and possess multiple functions represent characteristic features of intrinsically disordered proteins (IDPs) and intrinsically disordered protein regions (IDPRs); i.e., functional proteins or protein regions lacking unique tertiary structures. The aim of this paper is to provide an overview of the functional roles of human annexins and $\mathrm{S} 100$ proteins, and to use the protein intrinsic disorder perspective to explain their exceptional multifunctionality and binding promiscuity.
\end{abstract}

Keywords: annexin; S100 protein; $\mathrm{Ca}^{2+}$-binding protein; intrinsically disordered protein; protein-protein interactions; multifunctionality

\section{Introduction}

It is known that members of two large families of $\mathrm{Ca}^{2+}$-binding proteins, annexins and $\mathrm{S} 100$ proteins, can interact with each other in either a $\mathrm{Ca}^{2+}$-dependent or $\mathrm{Ca}^{2+}$-independent manner, leading the anexin-S100 complexes possessing biological activities [1]. Despite being $\mathrm{Ca}^{2+}{ }_{\text {-binding proteins, }}$ S100 proteins and annexins are very different, both structurally and functionally, with S100 proteins belonging to a superfamily of EF-hand proteins containing two $\alpha$-helices linked by a $\mathrm{Ca}^{2+}$-binding loop [2], and with annexins containing high affinity $\mathrm{Ca}^{2+}$-binding motifs known as annexin type II or type III motifs [3,4]. Members of both families play a number of crucial roles in regulation of different cellular processes, have multiple functions, and can interact with multiple partners, raising an important question of the applicability of classical "one gene-one protein-one function" concept to these proteins 
and even more important questions on the molecular mechanism of such multifunctionality and exceptional binding promiscuity, which are not too typical for ordered proteins with well-defined 3D structures.

Intrinsically disordered proteins (IDPs) or intrinsically disordered protein regions (IDPRs) can be defined as functional proteins or protein regions that lack ordered three-dimensional structures [5-15]. These proteins have the ability to bind to multiple partners, which enables them to function in regulation, signaling, and control, where they are commonly engaged in one-to-many and many-to-one interactions [5,7,11-13,16-22]. Disordered proteins or protein regions are often affected by post-translational modifications (PTMs), such as phosphorylation, glycosylation, methylation, and ubiquitylation [23,24], and serve as major targets for the alternative splicing (AS) [25-27]. All these means are utilized by nature to control and regulate functions of IDPs or hybrid proteins containing ordered domains and functional IDPRs. However, deregulation of IDPs is dangerous and these structure-less, highly dynamic, promiscuously interacting proteins/regions are implicated in numerous human diseases [28-30]. Since multifunctionality and binding promiscuity are typically rooted within the protein intrinsic disorder phenomenon, we looked here at the intrinsic disorder propensities of human annexins and S100 proteins and on the roles of intrinsic disorder in their physiological functions. In this article, available information on structures and functions of human annexins and S100 proteins is briefly considered followed by the description of extraordinary interactability of these proteins. Then, intrinsic disorder predisposition of human annexins and S100 proteins is analyzed. Finally, all these facts are brought together to show how proteoforms and structural polymorphism originating from intrinsic disorder can be used as a clue for understanding the multifunctionality and binding promiscuity of these proteins via the protein structure-function continuum concept.

\section{Structure and Functions of Human S100 Proteins}

Human S100 proteins represent a group of small (10-12 kDa) acidic regulatory metal-binding proteins containing 21 members, S100-A1, S100-A2, S100-A3, S100-A4, S100-A5, S100-A6, S100-A7, S100-A7A, S100-A7-like 2 (or S100-A7B), S100-A8, S100-A9, S100-A10, S100-A11, S100-A12, S100-A13, S100-A14, S100-A16, S100-B, S100-G, S100-P, and S100-Z. This family also includes two long proteins, 904-residue long trichohyalin-like protein 1 (S100-A17, also known as basalin) and 2850-residue-long hornerin (S100-A18), both containing S100 domains in their N-terminal regions. Majority of human S100 proteins are encoded by genes located on the human chromosome 1 (locus 1q21), where they represent a part of the epidermal differentiation complex, a chromosomal region that is frequently rearranged in cancer [31,32] and that contains a cassette of more than fifty genes encoding proteins involved in the terminal differentiation and cornification of keratinocytes. This localization of the majority of $\mathrm{S} 100$ genes on chromosome 1 defines their established nomenclature, where the consecutive Arabic numbers placed behind the stem symbols S100-A (e.g., S100-A1), whereas S100 genes located on other chromosomes carry the stem symbols S100 followed by a single letter (e.g., S100-B) [32,33].

Structurally, S100 proteins belong to the EF-hand superfamily [34-42], containing two $\mathrm{Ca}^{2+}{ }_{\text {-binding }}$ motifs, the C-terminally located canonical EF-hand with high $\mathrm{Ca}^{2+}$-binding affinity and the $\mathrm{N}$-terminal pseudo-EF-hand, also known as S100-specific EF-hand, which is characterized by the presence of two extra residues within the first half of the $\mathrm{Ca}^{2+}$-binding loop leading to the changed way of calcium coordination and decreased $\mathrm{Ca}^{2+}$-binding affinity [43]. Although amino acid sequences of S100 proteins (and S100 domains of basalin and hornerin) are rather diverse (for human S100 proteins, sequence identity ranges from $12.5 \%$ to $94.1 \%$, with mean sequence identity of this protein group being $30.6 \pm 9.9 \%$, see Supplementary Materials), these proteins are known to possess remarkable structural similarity. In fact, structures of all the S100 subunits characterized so far represent a four-helix bundle. However, the only monomeric representative of human S100 family is S100G (calbindin-D9k, also known as intestinal vitamin D-dependent calcium-binding protein), whereas the majority of S100 proteins exist as a symmetric homodimer, which is held together by the noncovalent interactions between two helices from each subunit (helices I, IV) that form an anti-parallel X-type four-helix 
bundle [44] (see Figure 1 showing all known structures of human S100 proteins). It is also known that some of the $\mathrm{S} 100$ homodimers are additionally stabilized by the interchain disulfide bridges, thereby forming covalently linked S100 dimers with specific cellular functions [45]. Furthermore, some of the S100 proteins are also able to form noncovalent heterodimers (for example, S100-A1/S100-A4, S100-A8/S100-A9, S100-B/S100-A1, S100-B/S100-A6, S100-B/S100-A11). One should also keep in mind, that the oligomerization potential of S100 proteins is not limited by the formation of homo- and heterodimers, and some S100 proteins are known to form tetramers, hexamers, and octamers that can serve as the active extracellular species needed for the receptor binding [46].

In addition to acting as $\mathrm{Ca}^{2+}$ sensors, some $\mathrm{S} 100$ proteins can also bind zinc and copper cations [42]. In fact, binding of divalent metal cations plays crucial roles in controlling functional properties of S100 proteins promoting homo- or hetero-oligomerization of S100 proteins and modulating their interactions with various specific partners, e.g., adenyl cyclase, caldesmon, cytoskeletal proteins, glycogen phosphorylase, microtubule associated proteins (MAP), nuclear kinase, and some cell cycle-associated proteins, such as neuromodulin and p53.

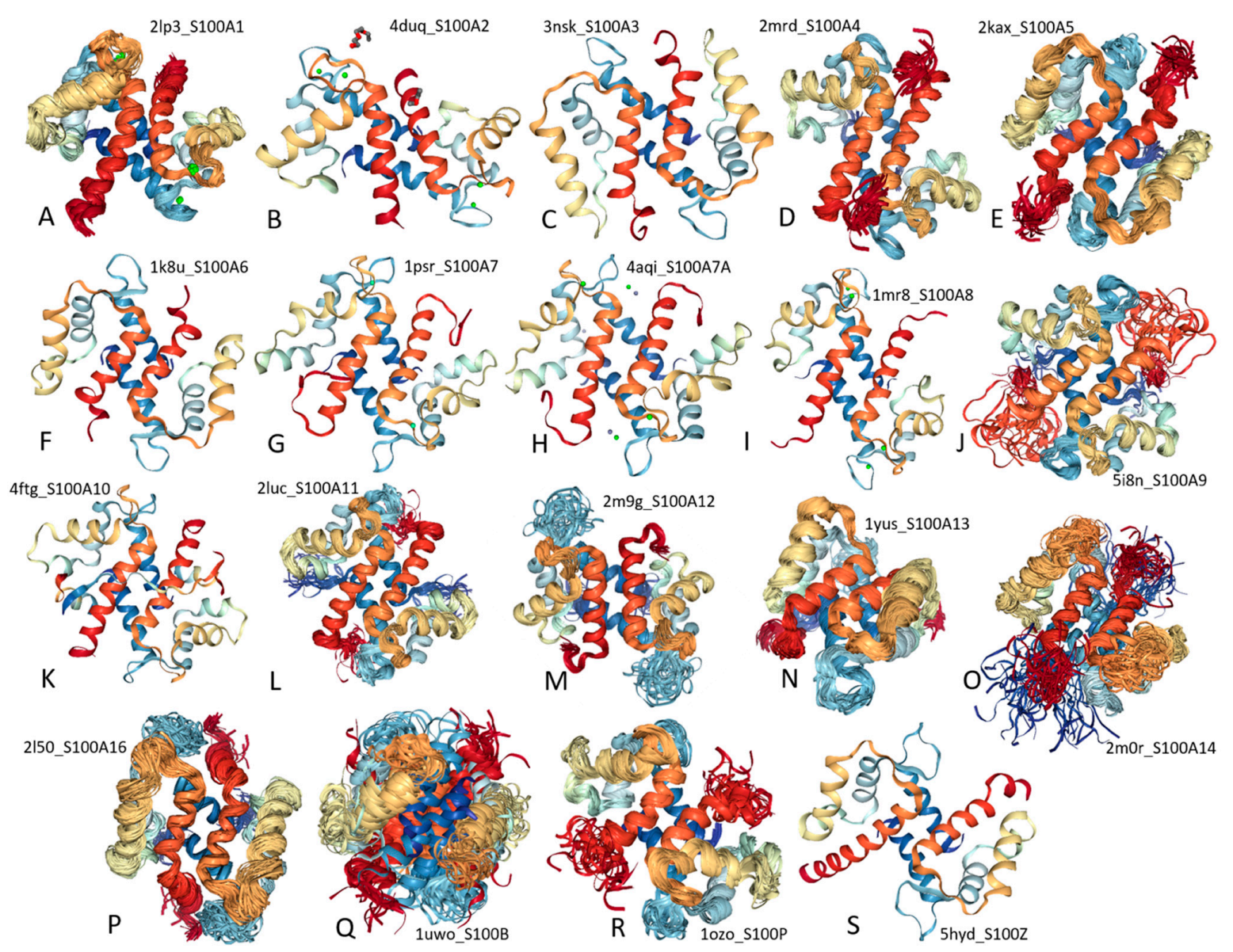

Figure 1. Structural characterization of human $\mathrm{S} 100$ proteins. solution NMR structures (plots A, D, E, J, $\mathbf{L}, \mathbf{M}, \mathbf{N}, \mathbf{O}, \mathbf{P}, \mathbf{Q}$, and $\mathbf{R}$ ) or X-ray crystallographic structures (plots $\mathbf{B}, \mathbf{C}, \mathbf{F}, \mathbf{G}, \mathbf{H}, \mathbf{I}, \mathbf{K}$, and $\mathbf{S}$ ) are shown for S100-A1 (A, PDB ID: 2LP3), S100-A2 (B, PDB ID: 4DUQ), S100-A3 (C, PDB ID: 3NSK), S100-A4 (D, PDB ID: 2MRD), S100-A5 (E, PDB ID: 2KAX), S100-A6 (F, PDB ID: 1K8U), S100-A7 (G, PDB ID: 1PSR), S100-A7A (H, PDB ID: 4AQI), S100-A8 (I, PDB ID: 1MR8), S100-A9 (J, PDB ID: 5I8N), S100-A10 (K, PDB ID: 4FTG), S100-A11 (L, PDB ID: 2LUC), S100-A12 (M, PDB ID: 2M9G), S100-A13 (N, PDB ID: 1YUS), S100-A14 (O, PDB ID: 2M0R), S100-A16 (P, PDB ID: 2L50), S100-B (Q, PDB ID: 1UWO), S100-P (R, PDB ID: 1OZO), and S100-Z (S, PDB ID: 5HYD). Note that no structural information is currently available for S100-A7B, S100-G, basalin (S100-A17), and hornerin (S100-A18). 
Functional diversification of S100 proteins can also be attained by their posttranslational modifications (e.g., phosphorylation $[47,48]$ ), binding to unsaturated fatty acids in a $\mathrm{Ca}^{2+}$-dependent manner [49], as well as due to their different affinities to bind divalent metal cations (calcium, copper, and zinc), different capabilities to form homo- and hetero-oligomers, specific cell and tissue expression patterns, the ability to localize in the cytosol and nucleus, or being secreted via a specific secretion pathway [50]. Since functionality of S100 proteins was a subject of multiple dedicated reviews $[35,36,39,51-56]$, there is no need for the detailed description of the multiple biological activities of these important proteins.

Because of their wide distribution and multifunctionality, S100 proteins contribute to a variety of intra- and extra-cellular processes, which range from $\mathrm{Ca}^{2+}$ homeostasis to blood coagulation, cell cycle regulation, cell growth and differentiation, cell migration and/or invasion, cell proliferation, cell survival, motility, organization of cytoskeleton, protein phosphorylation, regulation of enzyme activity, secretion, etc. Therefore, not surprisingly, misbehavior of S100 proteins is linked to a multitude of human diseases, such as allergies, asthma, various cancers, cardiomyopathy, diabetes, inflammatory disorders, neurodegeneration, psoriasis, and rheumatoid arthritis [46,57]. Some of the illustrative examples of the broad involvement of $\mathrm{S} 100$ proteins in pathogenesis of various human diseases are given by the overexpression of some S100 proteins in brains of patients with Alzheimer's disease or Down's syndrome [58], cancer patients [59], HIV-infected individuals [60], and several rheumatic diseases [61]. All this explains the attractiveness of S100 proteins as potential therapeutic targets [57,62-64].

\section{Structure and Functions of Human Annexins}

Annexins represent completely different family of $\mathrm{Ca}^{2+}$-binding proteins, which are significantly larger than $\mathrm{S} 100$ proteins, able to bind multiple $\mathrm{Ca}^{2+}$ ions, and whose $\mathrm{Ca}^{2+}$-binding sites are not EF-hand motifs (type I), but specific type II and type III sites $\mathrm{Ca}^{2+}$ binding sites located in loops [65]. Annexins constitute an evolutionary conserved multigene family of proteins, which have been described in most eukaryotic organisms [4]. In humans, there are 12 annexins (ANXA1-ANXA11 and ANXA13), of which ANXA7, ANXA11, and ANXA13 are considered the oldest members of the group, whereas the nine descendent annexins (ANXA1, ANXA2, ANXA3, ANXA4, ANXA5, ANXA6, ANXA8, ANXA9, and ANXA10) are assumed to originate from a common ancestor, ANXA11 [4]. Curiously, this evolutionary relationship is evident even from the phylogenetic tree that was built based on the multiple sequence alignment of just human annexins (see Supplementary Materials). Comparison of amino acid sequences of human annexins revealed that they share high sequence identity that ranges from $29.8 \%$ to $57.7 \%$, with mean sequence identity of this protein group being $44.3 \pm 6.9 \%$ (see Supplementary Materials).

A very characteristic feature of all annexins is the presence of several copies of an annexin repeat, which is $~ 70$-residue-long conserved structural element required for calcium and membrane binding function of annexins. The presence of such annexin repeats combined with the capability of a protein to interact with the negatively charged phospholipids in a $\mathrm{Ca}^{2+}$-dependent manner constitute major criteria defining annexins as a family. There are four such repeats in all human annexins except for ANXA6 that contains eight annexin repeats [4]. Each annexin repeat represents an easily identifiable element of the internal and inter-annexin sequence homology [3]. Figure 2 shows structural hierarchy of human annexins and represents an NMR solution structure of a single annexin repeat from ANXA1 (Figure 2A), an X-ray crystal structure of the full-length ANXA3 containing four annexin repeats (Figure 2B), an X-ray crystal structure of the monomeric ANXA6 containing eight annexin repeats (Figure 2C), and an X-ray crystal structure of the dimeric ANXA13 (Figure 2D). Figure 2A shows that annexin repeat is folded into a tightly packed structure containing five $\alpha$-helices. When placed together, four such repeats form a tightly packed and highly $\alpha$-helical disk with a slight curvature (Figure 2B). The convex side of annexins contains the type II and type III $\mathrm{Ca}^{2+}$ binding sites $[4,65]$. 
A

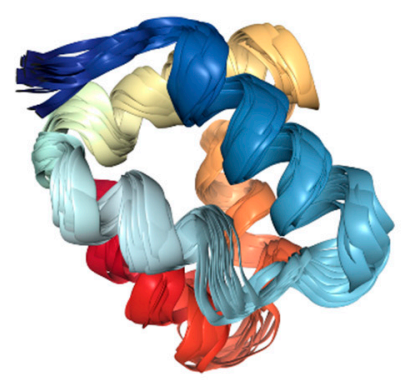

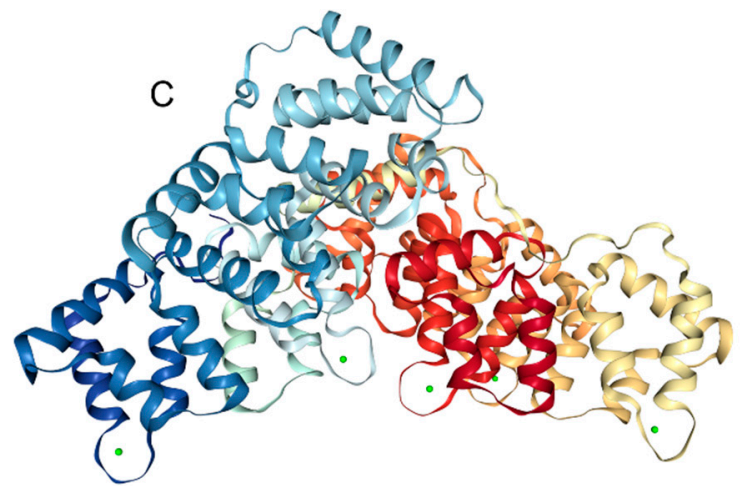

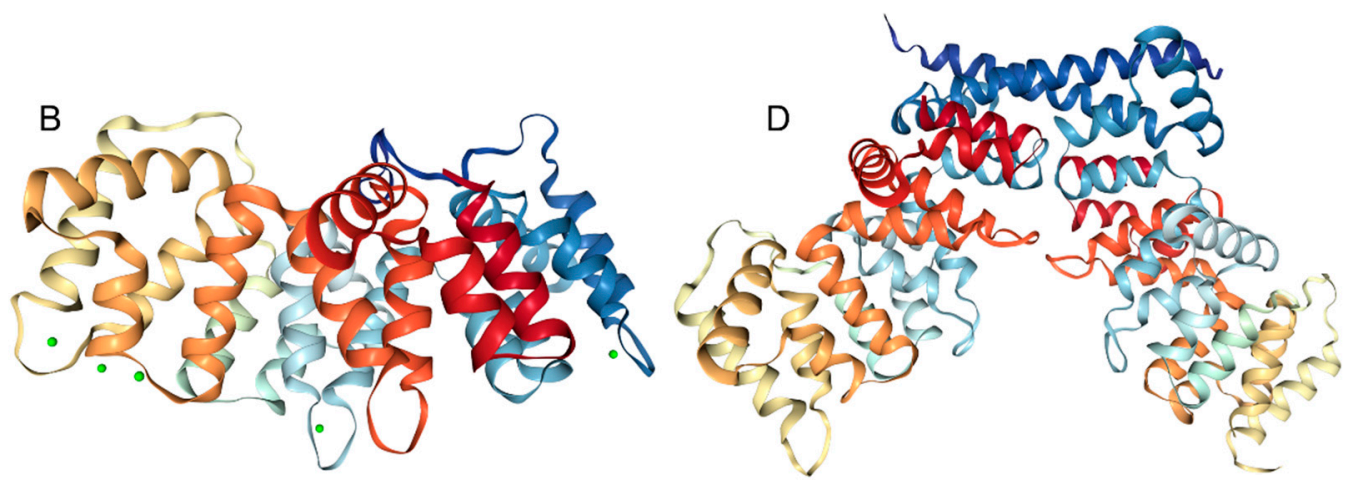

Figure 2. Structural characterization of human annexins. A. NMR solution structure of a single annexin repeat from ANXA1 (PDB ID: 1BO9). B. An X-ray crystal structure of the full-length ANXA3 containing four annexin repeats (PDB ID: $1 \mathrm{AXN}$ ). C. An X-ray crystal structure of the monomeric ANXA6 containing eight annexin repeats (PDB ID: 1M9I). D. An X-ray crystal structure of the dimeric ANXA13 (PDB ID: 6B3I).

This convex side is involved in the peripheral association of annexins with the phospholipid membranes [4]. The opposite side of this $\alpha$-helical disk is concave, points away from the membrane and can be utilized for interaction with specific binding partners or homodimerization via the N-terminal regions of annexin protomers (see Figure 2D). Finally, Figure 2C shows that ANXA6, which likely originated from the gene duplication during evolution [66], contains two disk-like shaped core lobes of four repeats connected via a flexible linker $[67,68]$ and able to bind to the phospholipid in both parallel and antiparallel orientation [68]. Because of their high sequence conservation, human annexins are structurally similar. This is illustrated by Figure 3 representing structural alignment of human ANXA2, ANXA3, ANXA4, ANXA5, a C-terminal half of ANXA6, ANXA8, and ANXA13. This figure represents four poses of structurally aligned annexins and shows their remarkable structural similarity (in fact, alignment of these structures over 257 residues is characterized by the RMSD of 1.03 $)$ ).

In addition to the conserved repeats forming characteristic disc-like $\mathrm{C}$-terminal core domain that contains $\mathrm{Ca}^{2+}$ and membrane binding sites and defines the membrane binding potential, annexins contain $\mathrm{N}$-terminally located head domain characterized by substantial sequence diversity and variable length. In fact, in ANXA1-ANXA11 and ANXA13, this domain includes 41, 32, 17, 13, 14, 19, 184, $20,40,16,199$, and 13 residues, respectively. In annexins with short $\mathrm{N}$-terminal domains ranging in length from 13 to 20 residues, this region typically extend along the concave side of the annexin, being involved in hydrophobic interactions with the protein core [4]. 

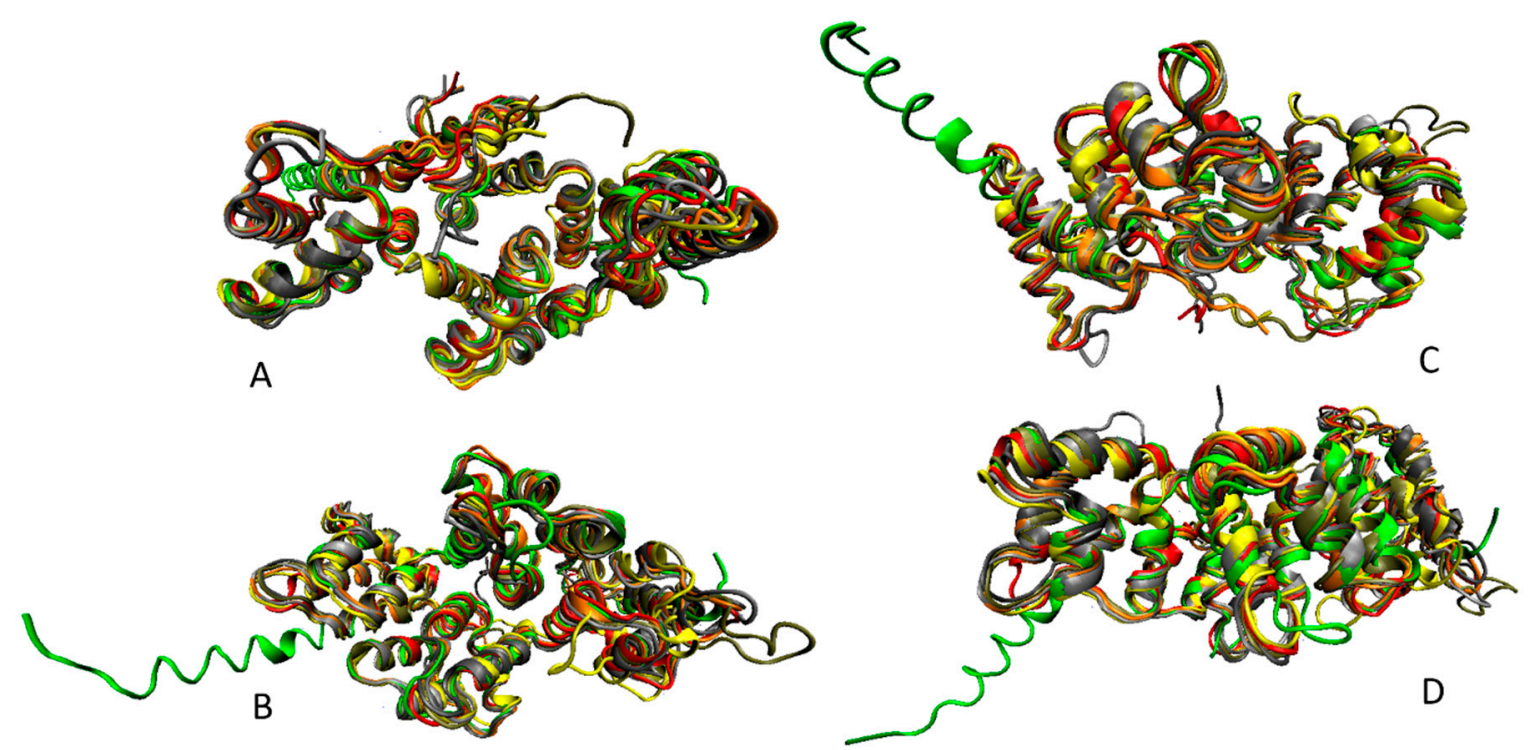

Figure 3. Multiple structural alignment of human annexins (ANXA2, PDB ID: 1W7B, red structure; ANXA3, PDB ID: 1AXN, gray structure; ANXA4, PDB ID: 2ZOC, orange structure; ANXA5, PDB ID: 1AVR, yellow structure; C-terminal half of ANXA6, PDB ID: 1M9I, tan structure; ANXA8, PDB ID: 1W3W, silver structure; and ANXA13, PDB ID: 6B3I, green structure) conducted by MultiProt server [69]. Structures were plotted using the VMD software [70].

These short N-terminal domains represent an important structural and functional unit that unfolds independently of the remaining protein structure [71] and have specific regulatory activities, e.g., affecting the $\mathrm{Ca}^{2+}$-dependent phospholipid binding of annexins likely due to the stabilization or destabilization of different conformations of these proteins [4]. Longer $\mathrm{N}$-terminal domains of annexins are involved in $\mathrm{Ca}^{2+}$ - and phospholipid-dependent interactions with various proteins. For example, the N-terminal residues 10-14 of ANXA1 represent a $\mathrm{Ca}^{2+}$-dependent binding site for the S100-A11 protein [72,73]. Similarly, in ANXA2, first 14 residues of the N-terminal domain constitute a binding site for the S100-A10 protein [74].

Annexins were originally described as proteins that bind to and hold together specific biological structures (e.g., membranes) and therefore act as scaffolding or bridging proteins. This property is reflected in the names of this protein family members, since "annexin" term is derived from the ancient


for multifunctional proteins, annexins were described in literature by different names related to their functionality or biochemical properties. Among various names given to annexins are calcimedins (proteins mediating $\mathrm{Ca}^{2+}$ signals [75]), calpactins (proteins binding $\mathrm{Ca}^{2+}$, phospholipid, and actin [76]), chromobindins (proteins binding to chromaffin granules [77]), lipocortins (steroid-inducible lipase inhibitors [78]), and synexin (for granule aggregating protein [79]), as well as anchorins, calelectrins, calphobindings, endonexins, placental anticoagulant proteins (PAPs), thromboplastin inhibitor, vascular anticoagulant- $\alpha$ (VAC- $\alpha)$ [80], etc.

Overall, it is believed that annexins serve as important constituents of the cellular calcium homeostasis displaying $\mathrm{Ca}^{2+}$-dependent structural and functional properties [4]. In line with these considerations, it was shown that annexins (particularly, ANXA1, ANXA2, ANXA4, and ANXA6) might form a sophisticated intracellular $\left[\mathrm{Ca}^{2+}\right]$ sensing system, being able to interact with the plasma membrane as well as with internal membrane systems in a highly coordinated and $\mathrm{Ca}^{2+}$-dependent manner, potentially providing means for regulation of other signaling pathways [81]. Being $\mathrm{Ca}^{2+} /$ phospholipid-binding proteins, annexins have to bind $\mathrm{Ca}^{2+}$ first in order to interact with membranes [3]. Although conserved core domains of all annexins can bind phospholipids in a $\mathrm{Ca}^{2+}$-dependent manner, there is a remarkable difference between these proteins in their sensitivity to 
$\mathrm{Ca}^{2+}$ and specificity for phospholipid head-groups [3]. Additional level of complexity in membrane binding by annexins is determined by their unique $\mathrm{N}$-terminal domains, which seem to contribute to the specific distribution of these proteins inside the cells [82-84]. Furthermore, some annexins e.g., ANXA1, ANXA2, ANXA4, ANXA6, and ANXA7, are not only capable of membrane binding but also mediate membrane vesicle aggregation [3]. Finally, at acidic $\mathrm{pH}$, where the native $\alpha$-helical structure is destabilized by protonation, some annexins can bind membranes independently of calcium. In this case, instead of peripheral interaction with the membrane, annexins assume a fully membrane-integrated structure with the seven-transmembrane-spanning topology [85-87]. Annexins also can function as scaffolding proteins to anchor other proteins to the cell membrane [4].

Because of their ability to bind membranes and proteins, annexins play a number of important roles in different cellular and physiological processes. For example, by providing membrane scaffold, annexins are related to changes in the shape of cells. They also participate in organization and trafficking of vesicles, calcium ion channel formation, cell-cell communication, endocytosis, and exocytosis [88]. Annexins found in the extracellular space can be involved in regulation of apoptosis, coagulation, fibrinolysis, and inflammation [89].

Misbehavior of multifunctional annexins is associated with various diseases. As a result, a special term "annexinopathies" was coined to describe pathological consequences of misbehaving annexins [90]. Several illustrative examples of such annexinopathies are represented below. Deregulation and aberrant posttranslational modifications of a glucocorticoid-regulated ANXA1, which is known to be related to adaptive and innate immunity via participation in the regulation of inflammatory cells and the resolution of inflammation, were linked to autoimmunity (e.g., systemic lupus erythematosus) [91]. Furthermore, abnormal expression of this protein is associated with preeclampsia (which is a pregnancy disease associated with impaired inflammatory response) [92] and is closely related to the occurrence and development of tumors, and metastasis [93]. Since ANXA1 is known to be involved in maintaining blood-brain barrier (BBB) integrity, achieved through co-localization with actin microfilaments present at the tight junctions between cells, deregulation of ANXA1 can be associated with BBB leaking [94] and therefore associated with age-related neurodegeneration [95] and multiple sclerosis [94].

Being widely distributed in the nucleus, cytoplasm, and extracellular surface of various eukaryotic cells, ANXA2 is implicated in various biological processes, such as apoptosis, $\mathrm{Ca}^{2+}$-dependent regulation of endocytosis and exocytosis, cell proliferation, focal adhesion dynamics, oxidative stress, interactions between cells and the extracellular matrix, as well as transcription, and translation [96]. ANXA2, likely via its complexation with $\beta_{2}$-glycoprotein $\mathrm{I}$, is involved in the pathogenesis of an autoimmune disease, antiphospholipid syndrome, characterized by arterial, venous or small-vessel thrombotic events, and recurrent miscarriages or fetal loss [97]. Elevated levels of this protein are also found in other autoimmune diseases and thrombotic associated diseases, such as pre-eclampsia [97]. Increased ANXA2 levels are correlated with invasion and metastasis in a variety of human cancers [98], and deregulation and aberrant expression of this protein are found in a large number of human diseases, such as autoimmune and neurodegenerative disease, antiphospholipid syndrome, inflammation, diabetes mellitus, and a series of cancers [99].

ANXA3 is shown to play a noticeable role in tumor formation, cell proliferation, apoptosis, invasion, metastasis, and drug resistance [100-103]. ANXA4 is altered in atherosclerotic coronary intima [104]. Curiously, although the levels of ANXA2 are increased in antiphospholipid syndrome [97], ANXA5 is under-expressed in this disease [90]. On the other hand, levels of ANXA5 are elevated in serum of all pregnant women on various stages of pregnancy, in serums of patients with several types of cancer [105], and in blood of patients with chronic disease of kidneys [106]. In the dysfunctional bladder, down-regulation of ANXA6 is related to the decline in the contractile properties of bladder [107]. Reduction in the ANXA7 levels is linked to the aggressive metastatic forms of prostate cancer [108] and is related to the suicidal death of erythrocytes, eryptosis [109]. ANXA8 expression is significantly upregulated in ductal carcinoma in situ (DCIS), which is an early form of breast cancer [110], and this protein was identified as one of the putative biomarkers in breast cancer [111]. ANXA9 and ANXA10 
expression is altered in head and neck squamous cell carcinomas (HNSCC) [112]. Mutations and deregulation of ANXA11 are related to the development, chemoresistance, and recurrence of cancers, as well as are found in sarcoidosis and systemic autoimmune diseases [113]. Finally, ANXA13 was identified as one of the best kidney biomarkers for refractory lupus nephritis (LN) [114].

\section{Interactability of Human Annexins and S100 Proteins}

It is clear that multifunctionality and polypathogenicity of human annexins and S100 proteins are related to the ability of these proteins to be engaged in multiple interactions with various partners. In agreement with this statement, Table 1 shows that according to the IntAct database (http://www.ebi.ac.uk/intact/) of binary interactions [115] and the STRING computational platform (Search Tool for the Retrieval of Interacting Genes; http://string-db.org/) [116] generating protein-protein interaction (PPI) networks based on the predicted and experimentally derived information on the interaction partners of a protein of interest, all members of both families of the human $\mathrm{Ca}^{2+}$-binding proteins analyzed in this study (annexins and S100 proteins) are involved in multiple interactions. In fact, even according to rather conservative IntAct-based estimations, majority of these proteins (24 of 35) have more than ten binding partners, whereas more relaxed STRING-based evaluation using medium confidence level of 0.4 shows that all human annexins and $\mathrm{S} 100$ proteins are expected to have more than ten partners, and four annexins (ANXA1, ANXA2, ANXA5, and ANXA7) and seven S100 proteins (S100A4, S100A7, S100A8, S100A9, S100A12, S100B, and S100A18) have more than 100 binding partners each. To further illustrate this point, Figure 4 represents PPI networks for the most connected annexin (ANXA1, Figure 4A) and most connected S100 proteins (S1007, Figure 4B). These networks were generated by STRING using the highest confidence of 0.9. STRING represents a platform conducting functional enrichment analysis of the protein-protein interaction (PPI) networks and contains PPI-related information for $24,584,628$ proteins from 5090 organisms [116]. STRING includes 3,123,056,667 known and predicted interactions, of which 52'857'362 interactions are at the highest confidence with the minimum required interaction score of $\geq 0.900$. These interactions represent direct (physical) and indirect (functional) associations and originate from computational prediction, knowledge transfer between organisms, as well as from the interactions aggregated from other (primary) databases [116]. STRING includes eight types of associations grouped into three classes shown in the corresponding PPI networks by different colors. These three groups include known interactions (derived from curated databases and experimentally determined shown as cyan and pink edges, respectively), predicted interactions (based on gene neighborhood, gene fusion, and gene co-expression indicated as green, red, and blue edges, respectively), and others (interactions derived from text mining, co-expression data, and protein homology shown as yellow, black, and light blue edges, respectively). STRING-generated PPI network as an interactive map containing large quantities of useful information. This STRING-based analysis revealed that the ANXA1-centered PPI network contains 354 nodes connected by 37,162 edges. In this network, the average node degree is 210 , and the average local clustering coefficient (which defines how close its neighbors are to being a complete clique; the local clustering coefficient is equal to 1 if every neighbor connected to a given node $N_{i}$ is also connected to every other node within the neighborhood, and it is equal to 0 if no node that is connected to a given node $N_{i}$ connects to any other node that is connected to $N_{i}$ ) is 0.942 .

Furthermore, since the expected number of interactions among proteins in a similar size set of proteins randomly selected from human proteome is equal to 5810, the inter-BAF PPI network has significantly more interactions than expected, being characterized by a PPI enrichment $p$-value of $<10^{-16}$. Analogous STRING-based analysis of S1007 shows that the corresponding PPI network has 86 nodes connected by 3655 edges. It is characterized by the average node degree of 78.1 , the average local clustering coefficient of 1.0, and a PPI enrichment $p$-value of $<10^{-16}$, since the expected number of edges is 180. Similar STRING-generated PPI networks for other annexins and S100 proteins are collected in Supplementary Materials. 
Table 1. Evaluating interactability of human annexins and S100 proteins.

\begin{tabular}{|c|c|c|c|c|c|}
\hline Protein Name & UniProt ID & $\mathbf{N}_{\text {IntAct }}$ & $\mathrm{N}_{\text {STRING (0.9) }}$ & $\mathrm{N}_{\text {STRING (0.7) }}$ & $\mathrm{N}_{\text {STRING (0.4) }}$ \\
\hline \multicolumn{6}{|c|}{ Annexins } \\
\hline ANXA1 & P04083 & 89 & 354 & 362 & 456 \\
\hline ANXA2 & P07355 & 102 & 99 & 119 & 268 \\
\hline ANXA3 & P12429 & 7 & 0 & 9 & 50 \\
\hline ANXA4 & P09525 & 11 & 0 & 2 & 60 \\
\hline ANXA5 & P08758 & 52 & 3 & 37 & 422 \\
\hline ANXA6 & P08133 & 24 & 6 & 10 & 62 \\
\hline ANXA7 & P20073 & 122 & 2 & 20 & 106 \\
\hline ANXA8 & P13928 & 13 & 0 & 4 & 36 \\
\hline ANXA9 & O76027 & 5 & 0 & 2 & 38 \\
\hline ANXA10 & Q9UJ72 & 3 & 0 & 3 & 36 \\
\hline ANXA11 & P50995 & 27 & 0 & 12 & 87 \\
\hline ANXA13 & P27216 & 0 & 0 & 5 & 38 \\
\hline \multicolumn{6}{|c|}{ S100 proteins } \\
\hline S100A1 & P23297 & 16 & 5 & 21 & 70 \\
\hline S100A2 & P29034 & 21 & 0 & 9 & 55 \\
\hline S100A3 & P33764 & 20 & 2 & 8 & 41 \\
\hline S100A4 & P26447 & 44 & 2 & 13 & 118 \\
\hline S100A5 & P33763 & 2 & 0 & 0 & 12 \\
\hline S100A6 & P06703 & 27 & 3 & 13 & 75 \\
\hline S100A7 & P31151 & 41 & 86 & 94 & 172 \\
\hline S100A7B & Q86SG5 & 8 & 0 & 3 & 20 \\
\hline S100A7A & Q5SY68 & 4 & 0 & 0 & 28 \\
\hline S100A8 & P05109 & 59 & 8 & 19 & 140 \\
\hline S100A9 & P06702 & 52 & 8 & 15 & 129 \\
\hline S100A10 & P60903 & 50 & 10 & 20 & 91 \\
\hline S100A11 & P31949 & 15 & 3 & 5 & 62 \\
\hline S100A12 & P80511 & 2 & 15 & 16 & 113 \\
\hline S100A13 & Q99584 & 18 & 4 & 6 & 48 \\
\hline S100A14 & Q9HCY8 & 15 & 0 & 4 & 40 \\
\hline S100A16 & Q96FQ6 & 12 & 0 & 10 & 24 \\
\hline S100B & P04271 & 30 & 19 & 51 & 231 \\
\hline S100Z & P29377 & 0 & 0 & 6 & 21 \\
\hline S100G & P25815 & 20 & 0 & 5 & 45 \\
\hline S100P & Q8WXG8 & 8 & 3 & 7 & 17 \\
\hline S100A17 & Q5QJ38 & 0 & 0 & 6 & 43 \\
\hline S100A18 & Q86YZ3 & 32 & 86 & 87 & 121 \\
\hline
\end{tabular}

Besides being engaged in interaction with large cohort of "external" partners, annexins and S100 proteins are known to interact with each other. This "internal" interactability extends beyond the ability of S100 proteins to for homo- and hetero-dimers and the oligomerization of annexins. In fact, several studies clearly indicated the presence of inter-family interactions and pointed out that the complexes between members of these two families are biologically significant $[1,117,118]$ 

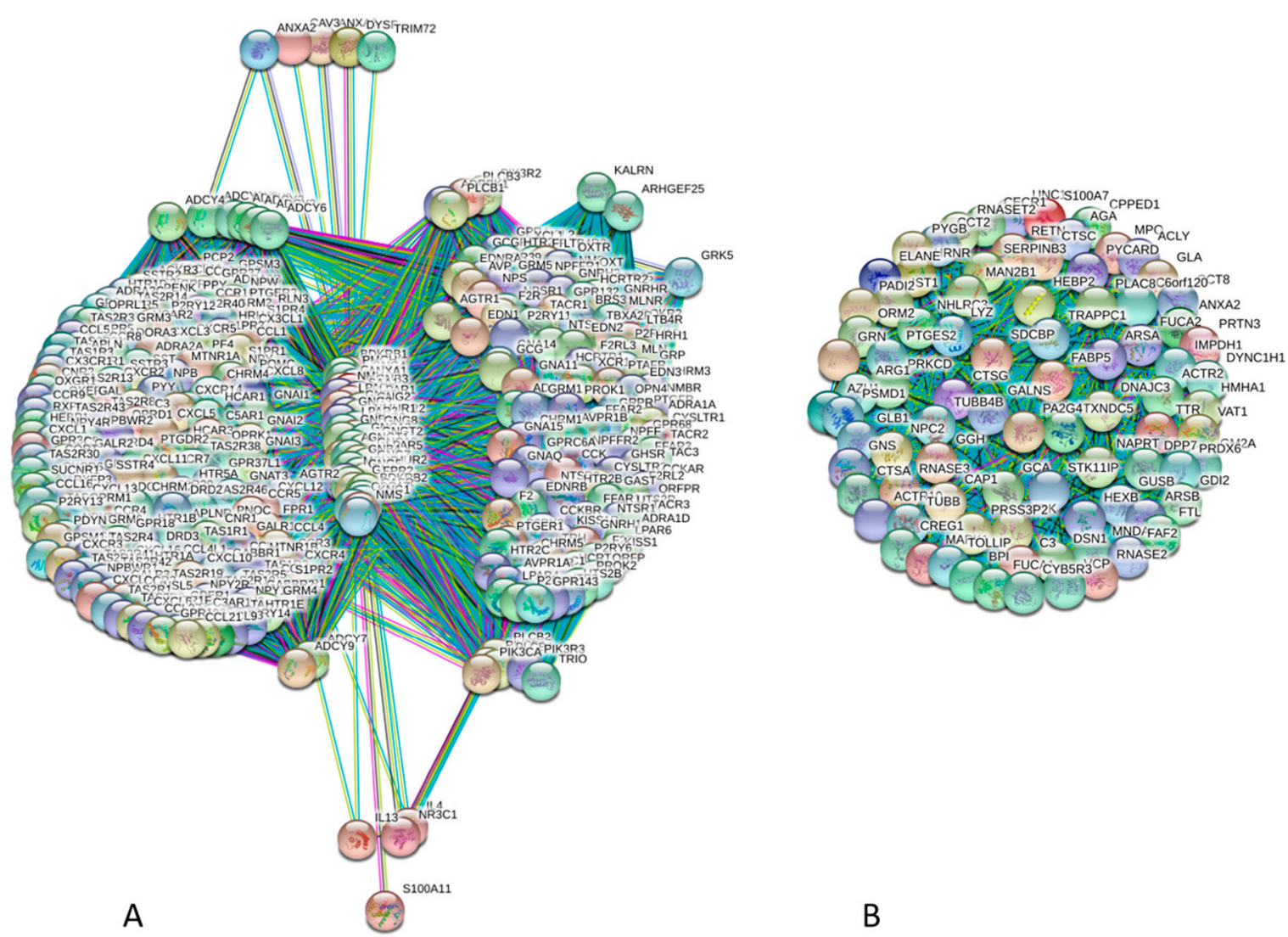

Figure 4. Illustrative examples of highly connected members of annexin and S100 proteins. These PPI networks were generated for ANXA1 (A, UniProt ID: P04083) and S1007 (B, UniProt ID: P31151) by computational platform STRING using the highest confidence of 0.9. STRING integrates all the information on protein-protein interactions (PPIs), complements it with computational predictions, and returns PPI network showing all possible PPIs of a query protein(s) [114]. The ANXA1-centered PPI network contains 354 nodes connected by 37,162 edges, whereas there are 86 nodes and 3655 edges in the S1007-centered PPI network.

Figure $5 \mathrm{~A}$ illustrates this inter-family interactivity by showing the PPI network between 12 human annexins and 23 human S100 proteins generated using STRING with the medium confidence of 0.4. This network includes 35 nodes and has the following characteristics: number of edges is 173, average node degree is 9.89 , averaged local clustering coefficient is 0.51 , expected number of edges is 3 , and PPI enrichment $p$-value is $<10^{-16}$. Figure $5 \mathrm{~B}$ shows the distributions of intra- and inter-family interactions for human annexins and S100 proteins. Analysis of this plot indicates that 21 proteins are involved in inter-family interactions. Furthermore, although the majority of S100 proteins (with the noticeable exception for S100A2, S100A10, S100A11, and S100A4) prefer S100 family members, all annexins show clear preference for interaction with S100 proteins. In agreement with the individual STRING profiles characterizing high interactability of different members of the annexin and S100 families Figure 6A represents the global annexin-S100-centered interactome that includes 535 nodes connected by 44,201 edges. This network was generated using STRING platform in the multi-protein mode to analyze the interactions of the 12 human annexins and 23 humans S100 proteins with 500 proteins forming the first shell of the resulting interactome (note that the number of interactors in STRING is limited to 500). In this analysis, the medium confidence level of 0.4 was used. Analysis of this dense PPI network indicated that the resulting interactome is characterized by an average node degree of 165 and shows an average local clustering coefficient of 0.798 . 

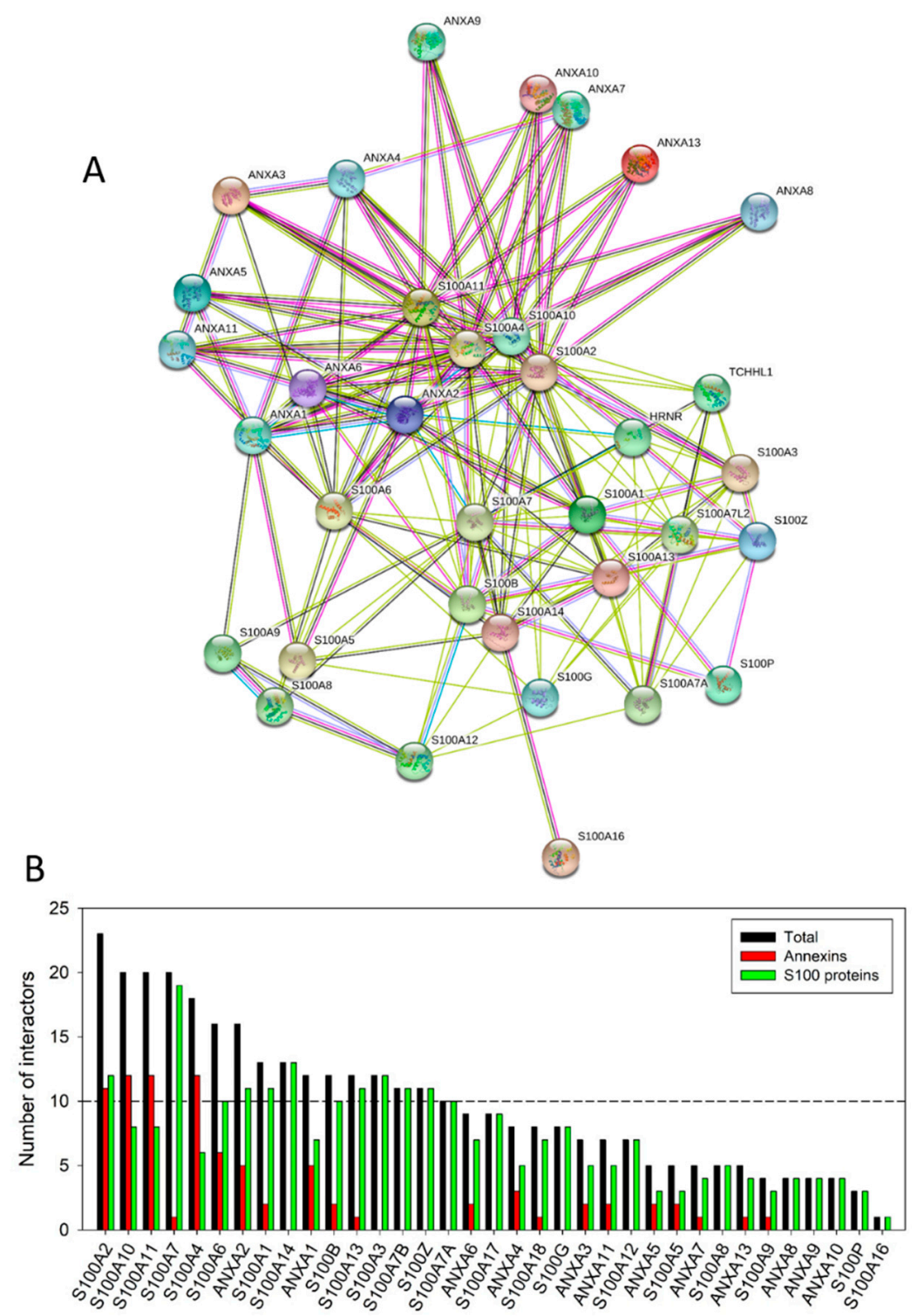

Figure 5. Analysis of the intra-family and inter-family interactivity of human annexins and S100 protein. (A) The inter-family interactivity is illustrated by the PPI network between 12 human annexins and 23 human S100 proteins generated by STRING with the medium confidence of 0.4. In this network, 35 human calcium-binding proteins are connected by 173 edges. (B) The distributions of intra- and inter-family interactions for human annexins and S100 proteins. For each protein three bars are shown corresponding to the total number of interactions with other annexins and S100 proteins (black bar), the number of its interactions with annexins (red bar) and the number of its interactions with S100 proteins (green bar).

The expected number of interactions for the set of proteins of its size is 6968, indicating this annexin-S100-centered-centered PPI network has significantly more interactions than expected (PPI enrichment $p$-value is $<10^{-16}$ ). Figure $6 \mathrm{~B}$ compares involvement of each member of the human annexin and S100 families in annexin-S100 interfamily network and in a global annexin-S100-centered interactome and shows that there is a weak correlation between these two parameters. 


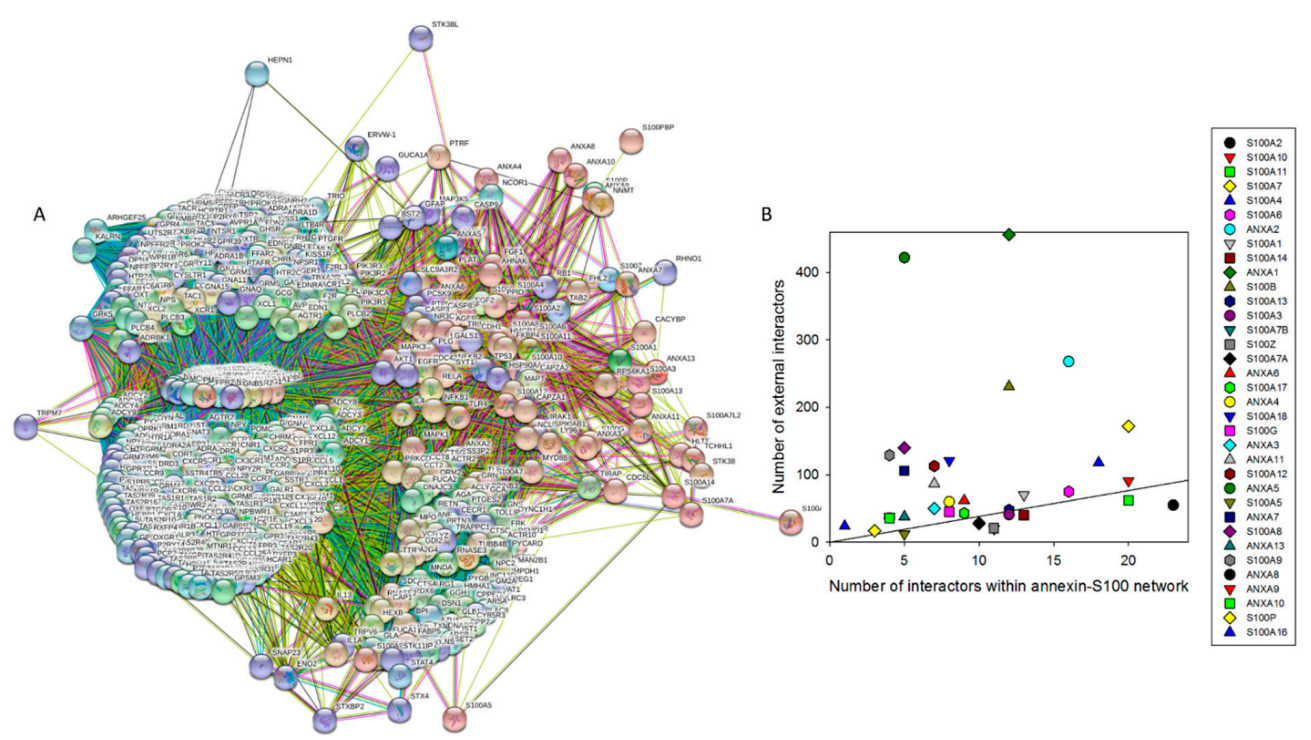

Figure 6. Evaluation of the global interactivity of human annexins and S100 proteins by STRING platform. (A) Global annexin-S100-centered interactome that includes 535 nodes connected by 44,201 edges. In this analysis, the medium confidence level of 0.4 was used. (B) Comparison of the involvement of each member of the human annexin and S100 families in annexin-S100 interfamily network and in a global annexin-S100-centered interactome.

\section{Intrinsic Disorder as a Common Denominator for Understanding the Multifunctionality of Annexins and S100 Proteins}

We are showing here that members of both $\mathrm{Ca}^{2+}$-binding families considered in this study possess extensive interactability, forming dense and highly connected PPI networks. Since both families are characterized by considerable structural conservation, such binding promiscuity is rather surprising, since, typically, proteins with similar structures are expected to have similar functions. The solution to this conundrum is coming from considering the protein intrinsic disorder phenomenon. In fact, the ability to be engaged in a wide range of interactions with multiple, often unrelated, binding partners represents a characteristic feature of IDPs and intrinsically disordered protein regions IDPRs; i.e., functional proteins or protein regions lacking unique tertiary structures [5-9,16,18,19,119-129]. As a result of their structural plasticity, these proteins/regions were shown to bind to different targets, adopting different conformations at interaction with distinct targets $[9,119,121,129,130]$. Therefore, the presence of functional IDPRs represents one of the likely explanations for the binding promiscuity of human annexins and S100 proteins. In line with this hypothesis, some of the regions in various S100 proteins, such as $\mathrm{Ca}^{2+}$-binding loops, the linker loop connecting the two sub-domains of the protein ('hinge'), helix III, and the N- and C-termini, were previously characterized as regions with increased mobility [131-134]. Similarly, structural flexibility was also described for the N-terminally located head domains of annexins, which are characterized by substantial sequence diversity and variable length, ranging from 20 to 199 residues. As it was already pointed out, although short $\mathrm{N}$-terminal domains are typically involved in hydrophobic interactions with the protein core [4], they represent a unique functional and regulatory unit that unfolds independently of the remaining protein structure [71] and can affect the $\mathrm{Ca}^{2+}$-dependent phospholipid binding of annexins via the differential alterations of their different conformations [4]. Longer N-terminal domains were shown to be engaged in $\mathrm{Ca}^{2+}$ and phospholipid-dependent interactions of annexins with various proteins [72-74], and contribute to the intracellular distribution of annexins [82-84]. Curiously, N-terminal regions of some annexins are expelled from the core domain as a result of calcium binding [117].

These observations called for the comprehensive analysis of the intrinsic disorder predisposition of the members of the annexin and S100 families. Such an analysis can be conducted by various predictors of intrinsic disorder, which are the specialized computational tools designed to retrieve the 
information on the intrinsic disorder predisposition of a query protein from its amino acid sequence alone. The outputs of these tools are disorder profiles showing intrinsic disorder predisposition for each residue in a sequence. A residue/region is classified as intrinsically disordered if it is characterized by the predicted disorder score (PDS) $\geq 0.5$, and it is flexible if its $0.15 \leq \mathrm{PDS}<0.5$. The intrinsic disorder status of a query protein is determined based on several measures, such as the overall percent of predicted disordered residues, the number and lengths of its IDPRs, and the mean disorder score.

Figure 7 represents the results of the PONDR ${ }^{\circledR}$ VSL2-based $[135,136]$ analysis of the per-residue intrinsic disorder predisposition of human annexins and S100 proteins. Although the majority of annexins and S100 proteins are characterized by fairly uniform sequence length (the average length of nine annexins is $329 \pm 12$ residues and 21 S100 proteins contain on average $98 \pm 7$ residues), there are noticeable exceptions from this rule. Here, ANXA6, ANXA7, and ANXA11 contain 673, 488, and 505 residues, respectively, and S100A17 and S100A18 are 904 and 2850-residue long.
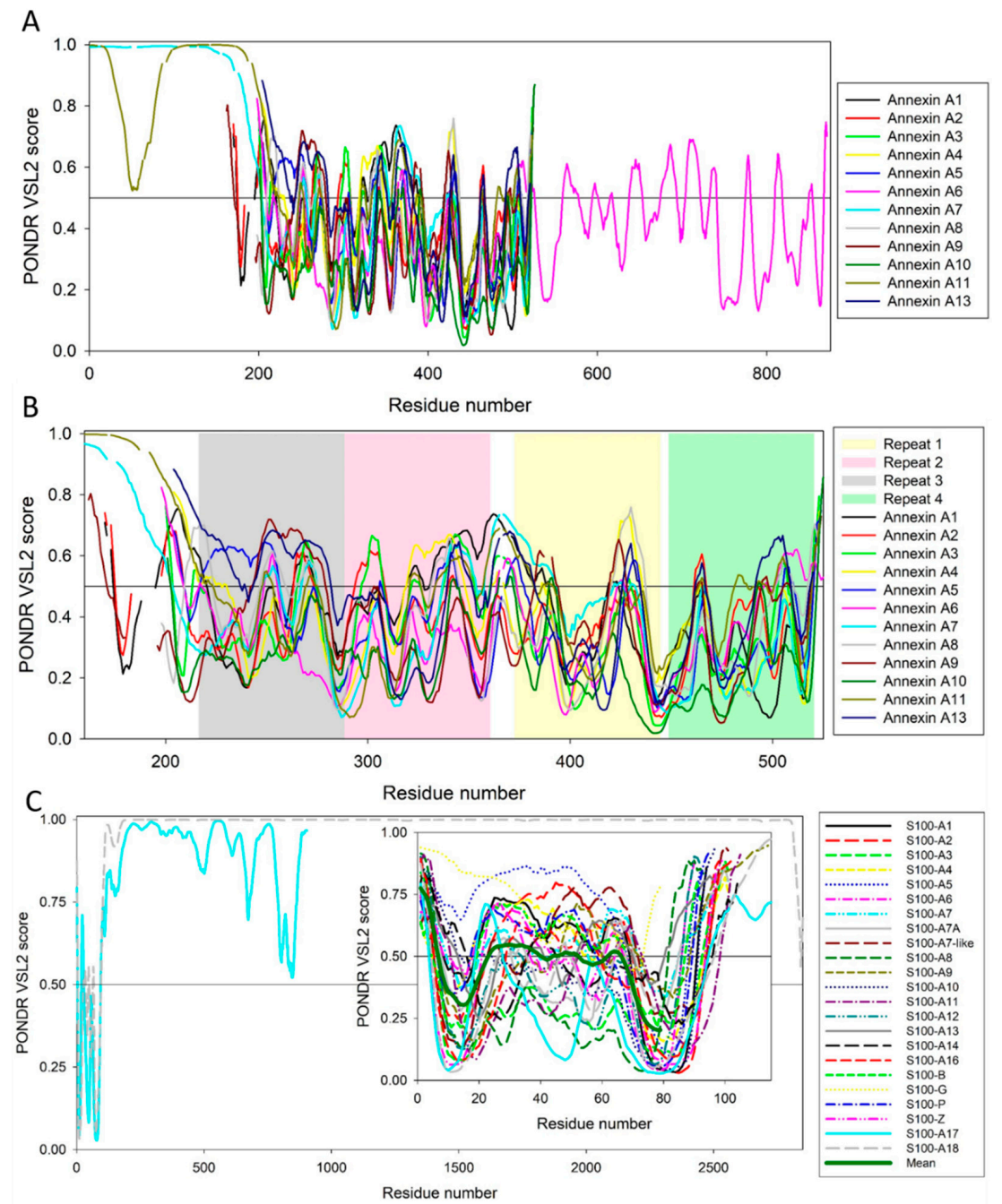

Figure 7. Evaluation of the per-residue intrinsic disorder predispositions of human annexins (A,B) and S100 proteins $(\mathbf{C})$. This analysis was conducted using PONDR ${ }^{\circledR}$ VSL2-based. Plot A contains PONDR ${ }^{\circledR}$ VSL2-generated profiles of the aligned annexins. Plot $\mathbf{B}$ represents disorder profiles of aligned core domains of human annexins. Plot $\mathrm{C}$ shows disorder profiles of 904-residue long basalin (S100-A17) and 2850-residue-long hornerin (S100-A18). N-terminal regions of both proteins contain short ( 100 residues) partially ordered domains, with the remaining 800 and 2750 residues of S100-A17 and S100-A18 being highly disordered. Inset to this plot represents PONDR ${ }^{\circledR}$ VSL2 profiles of the N-terminal sections of these two proteins and all other human S100 proteins. 
To account for this remarkable length difference between the different family members, we present corresponding disorder-based "family portraits" in two forms, (1) where the disorder profiles of all the family members are overlaid (annexins, Figure 7A) or disorder profiles of longest members are shown (S100 proteins, Figure 7C), and (2) disorder profiles focused on core domains of annexins (Figure 7B) or S100 proteins (inset to Figure 7C). Figure 7A shows that long N-terminal head domains of ANXA7 and ANXA11 are expected to be highly disordered, and the C-terminal half of ANXA6 is more disordered than its N-terminal half. On the other hand, peculiarities of disorder distribution within the sequences of core domains of human annexins are fairly conserved, since all of them show remarkably similar disorder profiles (see Figure 7B). This is in sharp contrast with the disorder predispositions of the calcium binding domains of S100 proteins, which, in agreement with previous study [137] are characterized by rather different disorder profiles. On the other hand, Figure 7 shows that on average, all annexins and S100 proteins contain rather high levels of intrinsic disorder.

This is further illustrated by Figure 8 representing 2D disorder plots for these proteins, where the percentages of predicted intrinsically disordered residues evaluated by PONDR ${ }^{\circledR}$ VSL2 $[135,136]$ (PPIDVSL2) are plotted against the percentages of predicted intrinsically disordered residues evaluated by PONDR ${ }^{\circledR}$ VLXT [138] (PPID VLXT). These data can be used to roughly classify proteins as highly ordered, moderately or highly disordered based on their corresponding PPID values. In this accepted PPID-based classification, proteins are considered as highly ordered, moderately disordered, or highly disordered if their PPID $<10 \%, 10 \% \leq$ PPID $<30 \%$, or PPID $\geq 30 \%$, respectively [139]. Figure 8 shows that none of the annexins or $\mathbf{S 1 0 0}$ proteins is classified as highly ordered by both predictors (there is no symbols within the $10 \%$ square). On the other hand, the majority of annexins (ANXA2, ANXA3, ANXA4, ANXA5, ANXA6, ANXA8, ANXA9, and ANXA10) and three S100 proteins (S100A3, S100A10, and S100A12) are predicted to be moderately disordered by both predictors, and remaining members of these two families are predicted as highly disordered by at least one of the predictors. The fact that all annexins are expected to be at least moderately disordered is rather unexpected, since many of these proteins were shown to have unique structures even in their calcium-free states. Furthermore, Figure 7B shows that disorder propensity is unevenly distributed within the individual annexin repeats, with the $\mathrm{N}$-terminal repeats 1 and 2 being typically more disordered than the $\mathrm{C}$-terminal repeats 3 and 4 .

It is likely that the IDPRs found in annexins can be of functional importance. It was already pointed out that the head domains of annexins (note that all of them are predicted to contain high levels of disorder) are known to play crucial biological functions. For example N-terminal regions of some annexins, such as ANXA1 and ANXA2 are expelled from the core domain on calcium binding [117]. Importantly, the N-terminal residues 10-14 of ANXA1 represent a $\mathrm{Ca}^{2+}$-dependent binding site for the S100-A11 protein $[72,73]$. Furthermore, it was shown that the ANXA1 N-terminal peptide (residues 1-26) possesses random coil structure in aqueous solution but fold into an $\alpha$-helical structure upon binding to the small unilamellar vesicles, suggesting that this $\mathrm{N}$-terminal domain of ANXA1 can serve as a secondary membrane binding site in the process of membrane aggregation by providing a peripheral membrane anchor $[140,141]$. Similarly, in ANXA2, first 14 residues of the N-terminal domain constitute a binding site for the S100-A10 protein [74]. The head domain of ANXA13 can contribute to the alternative fold of the $\mathrm{N}$-terminal region of this protein, where the first two $\alpha$-helices and the associated helix-loop-helix motif are converted into a continuous $\alpha$-helix and are used as to form a domain-swapped dimeric form of this protein [142]. To gain more information on potential functional roles of IDPRs in human annexins, these proteins were subjected to the complementary disorder analysis using the $\mathrm{D}^{2} \mathrm{P}^{2}$ platform (http://d2p2.pro/) [143], which is a database of predicted disorder for a large library of proteins from completely sequenced genomes [143]. $\mathrm{D}^{2} \mathrm{P}^{2}$ database uses outputs of several per-residue disorder predictors, such as IUPred [144], PONDR ${ }^{\circledR}$ VLXT [138], PrDOS [145], PONDR ${ }^{\circledR}$ VSL2 [135,136], PV2 [143], and ESpritz [146]. The database is further supplemented by the data on the locations of predicted SCOP domains, conserved Pfam domains, as well as sites of various posttranslational modifications and predicted disorder-based protein binding sites, known as 
molecular recognition features, MoRFs [143]. It is known that many disorder-based binding regions are characterized by the presence of less disordered sub-regions, which are not capable of folding on their own, but can undergo binding-induced folding at interaction with its binding protein partner. In disorder profiles, such regions are typically manifested as local "dips" within the regions with high disorder score $[147,148]$. In $\mathrm{D}^{2} \mathrm{P}^{2}$, the presence of MoRFs is evaluated by ANCHOR algorithm $[149,150]$.

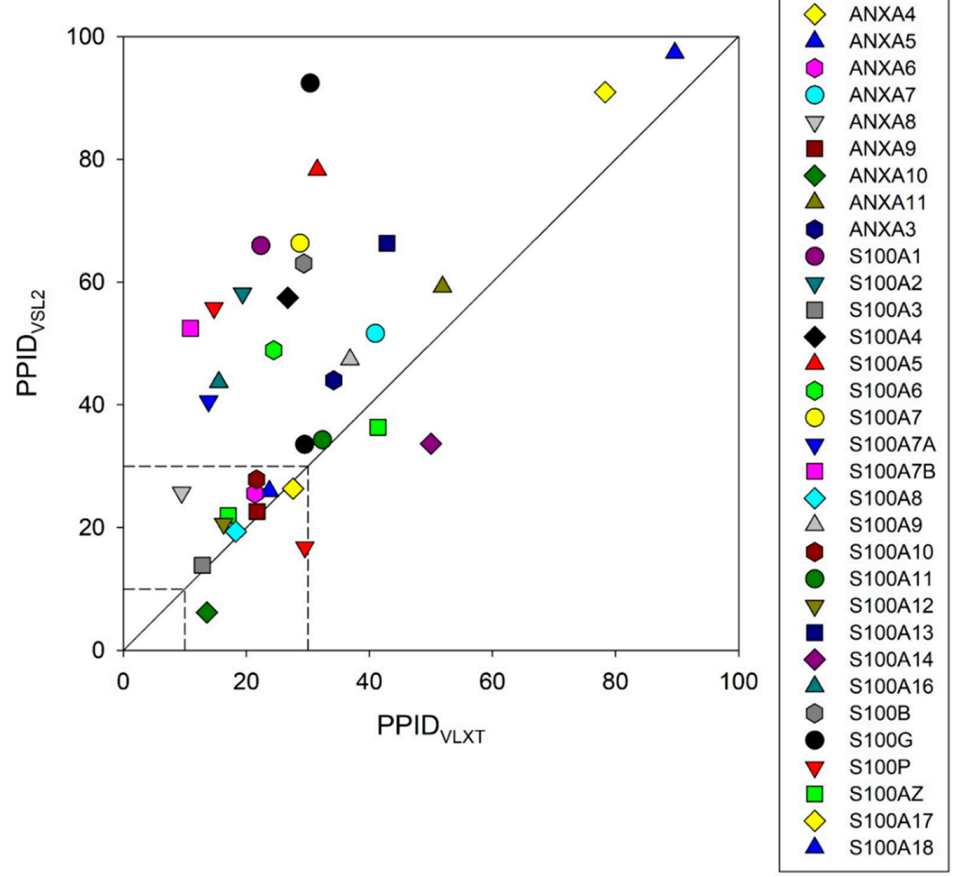

Figure 8. 2D representation of the results of evaluation of disorder levels of human annexin and S100 proteins. Here, the percentages of residues in these proteins predicted to be disordered by PONDR ${ }^{\circledR}$ VSL2 are compared with their percentages of disordered residues predicted by PONDR ${ }^{\circledR}$ VLXT. The goal of this plot is to show the overall agreement between the outputs of different disorder predictors used in this study and to show high level of disorder in analyzed proteins.

Results of this analysis for 11 human annexins are shown in Figure $9\left(\mathrm{D}^{2} \mathrm{P}^{2}\right.$ does not contain information on human ANXA4). Analysis of these functional disorder profiles reveals that in addition to possessing variable levels of intrinsic disorder, all human annexins contain numerous sites of PTMs and six annexins (ANXA1, ANXA2, ANXA6, ANXA7, ANXA10, and ANXA13) are predicted to have MoRFs. Curiously, positions of MoRFs in ANXA1, ANXA2, and ANXA13 coincide with the positions of the aforementioned functionally important parts of N-terminal head domains of these proteins. Since head domains are longest and most disordered ANXA7 and ANXA10, it is not surprising that each of these proteins have multiple long MoRFs. Analogous conclusions can be made based on the $\mathrm{D}^{2} \mathrm{P}^{2}$ analysis of 22 human $\mathrm{S} 100$ proteins (there is no $\mathrm{D}^{2} \mathrm{P}^{2}$ profile for $\mathrm{S} 100 \mathrm{~A} 2$ ). Figure 10 shows that almost all of S100 proteins are intensively decorated by various PTMs, and nine of them have MoRFs, with very significant parts of highly disordered S100A17 and S100A18 representing disorder-based binding regions. In addition to various PTMs, sequence diversity of human annexins is further enhanced by alternative splicing (AS). ANXA1 has one experimentally validated isoform (346 residues) and two computationally mapped potential isoforms (205 and 114 residues). Canonical isoform of ANXA2 contains 339 residues, whereas AS-generated isoform is extended to 357 residues due to the $\mathrm{M}_{1} \rightarrow$ MGRQLAGCGDAGKKASFKM that adds a disordered stretch to the N-terminal head domain. Although experimental evidence is available only for one ANXA3 isoform (323 residues), at least five potential isoforms with the lengths of 55, 104, 134, 154, and 284 residues are computationally mapped. 

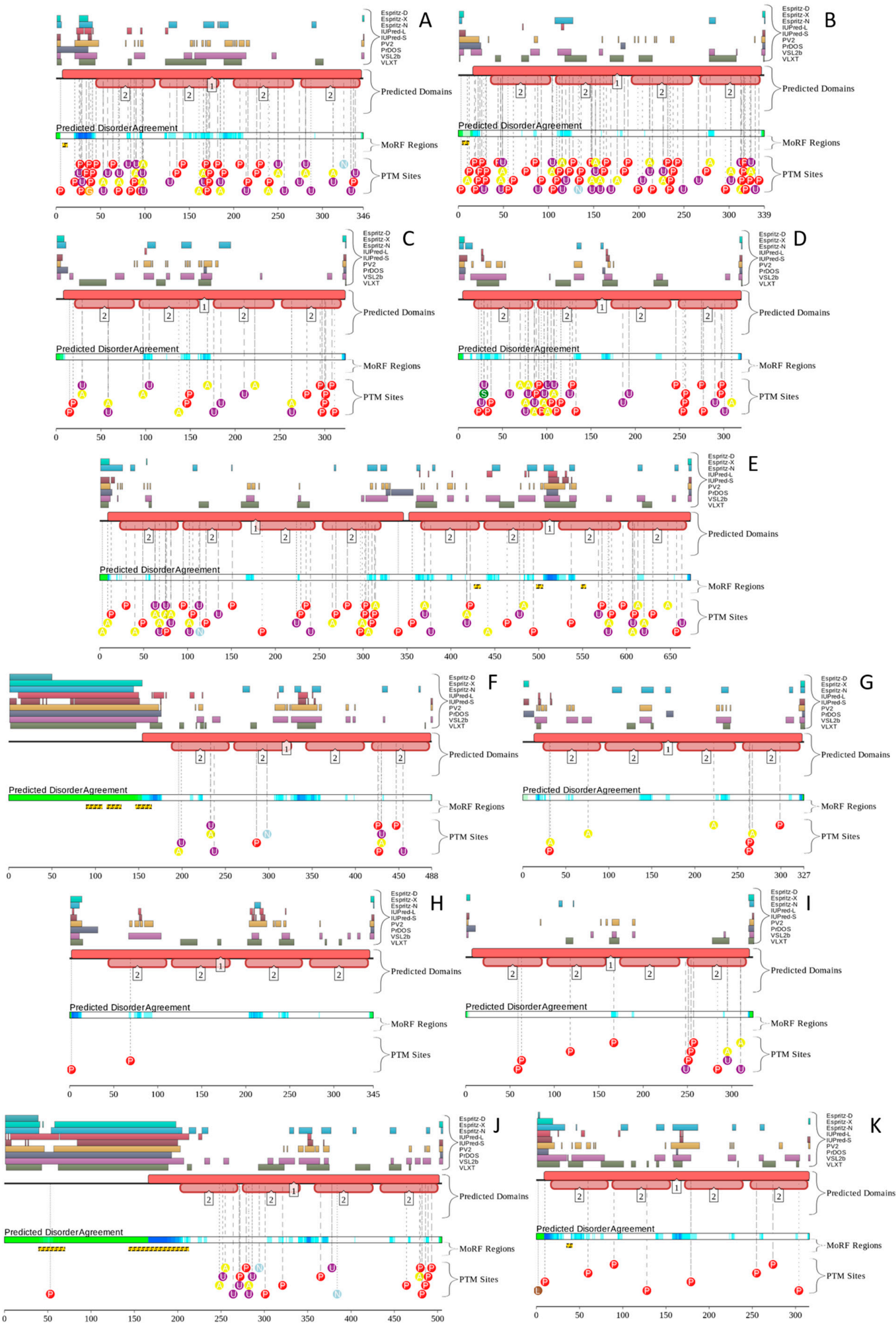

Figure 9. Functional disorder profiles of human annexins generated by the $\mathrm{D}^{2} \mathrm{P}^{2}$ platform (http: //d2p2.pro) that generates an interactive display that comments on the structural components, disordered segments, post-translational modifications (PTMs), and the presence of disorder-based binding sites 
in a protein of interest [139]. A, ANXA1; B, ANXA2; C, ANXA3; D, ANXA5; E, ANXA6; F, ANXA7; G, ANXA8; H, ANXA9; I, ANXA10; J, ANXA11; K, ANXA13. Note that no D $\mathrm{P}^{2}$ profile is currently available for human ANXA4. At the top of each figure, there is a side by side comparison of seven separate disorder predictors (Espritz-D, Espritz-X, Espritz-N, IUPred-L, IUPred-S, PV2, PrDOS, VSL2b, and VLXT), bars indicate positive hits for disorder prediction. Below these colored bars there are two bars showing the position of predicted SCOP domains and conserved Pfam domains. The middle of each plot contains a bar labeled "Predicted Disorder Agreement" presenting the level of agreement between all of the disorder predictors, which is shown as color intensity in an aligned gradient bar below the stack of predictions. The green segments represent disorder that is not found within a predicted SCOP domain. The blue segments are where the disorder predictions intersect the SCOP domain prediction. Below the disorder agreement line, disorder-based binding region (i.e., disordered regions that fold upon interaction with binding partners and known as molecular recognition features, MoRFs) predicted by ANCHOR are displayed as yellow blocks with zigzag infill. Finally, the bottom of the plot shows positions of various PTMs within the query proteins. These are shown by differently colored circles containing letter A (acetylation), L (lipidation), N (nitrosylation), P (phosphorylation), $\mathrm{S}$ (sumoylation), and U (ubiquitylation).

Similarly, ANAX5 has a validated isoform of 320 residues and five computationally mapped isoforms with 35, 163, 220, and 260 residues. In addition to the canonical isoform of 319 residues, ANXA4 can exist as an AS-generated isoform (237 residues) with missing residues 1-82. ANXA6 has two described isoforms (canonical isoform with 673 residues and AS isoform with missing residues 1-32) and nine potential isoforms that are computationally mapped (91, 95, 110, $2 \times 129$, 150, 156, 330, and 460 residues). ANAX7 has a canonical (488 residues) isoform, an AS-generated isoform that misses residues 146-167, and a computationally mapped isoform with 144 residues. For ANAX8, there are three described isoform, a canonical isoform containing 327 residues and two AS isoforms, where isoform 2 (141 residues) has a DYGS $\rightarrow$ GQQG in region 138-141 and is also missing residues 142-327, whereas residues 8-69 are missing in isoform 3 (265 residues). There are also three computationally mapped isoforms of this protein that contain 21, 276, and 365 residues. Canonical form of ANAX11 contains 505 residues, its AS-generated isoform (472 residues) is missing a part of the $\mathrm{N}$-terminal head domain (residues 1-33), and two computationally mapped isoforms with 148 and 150 residues. The AS-generated isoform of ANXA13 (357 residues) is different from the canonical isoform (316 residues) by the presence $\mathrm{H} \rightarrow$ HSQSYTLSEGSQQLPKGDSQPSTVVQPLSHPSRNGEPEAPQP substitution that which is expected to be highly disordered. Finally, no isoforms were described for ANXA9 and ANXA10.

Very similar situation is observed for human S100 proteins, some of which also have multiple computationally mapped isoforms. The corresponding information is shown below in a form, where a protein name is followed by the series of numbers corresponding to the length of its isoforms, with number of residues in described isoform shown in bold: S100A1 (94, 34, 53, 147), S100A2 (98, 64, 95), S100A6 $(\mathbf{9 9}, 85)$, and S100B $(\mathbf{9 2}, 94)$. For S100A5 two isoforms are produced by alternative splicing, canonical isoform 1 (92 residues) and isoform 2 (110 residues) with $\mathrm{M}_{1} \rightarrow$ MPAAWILWAHSHSELHTVM substitution. No isoforms were described for the remaining S100 proteins (S100A3, S100A4, S100A7, S100A7A, S100A7B/S100A7L2, S100A7, S100A9, S100A10, S100A11, S100A12, S100A13, S100A14, S100A14, S100G, S100P, S100Z, and S100A17/Basalin, and S100A18/Hornerin).

\section{Intrinsic Disorder and S100-Annexin Aomplexes}

Structural and functional aspects of various S100-annexin complexes are covered in excellent dedicated reviews [1,117]. In fact, S100A1, S100A4, S100A6, S100A10, S100A11, S100A12, and S100B can interact with annexins, and ANXA1, ANXA2, ANXA5, ANXA6, and ANXA11 can interact with S100 proteins. 


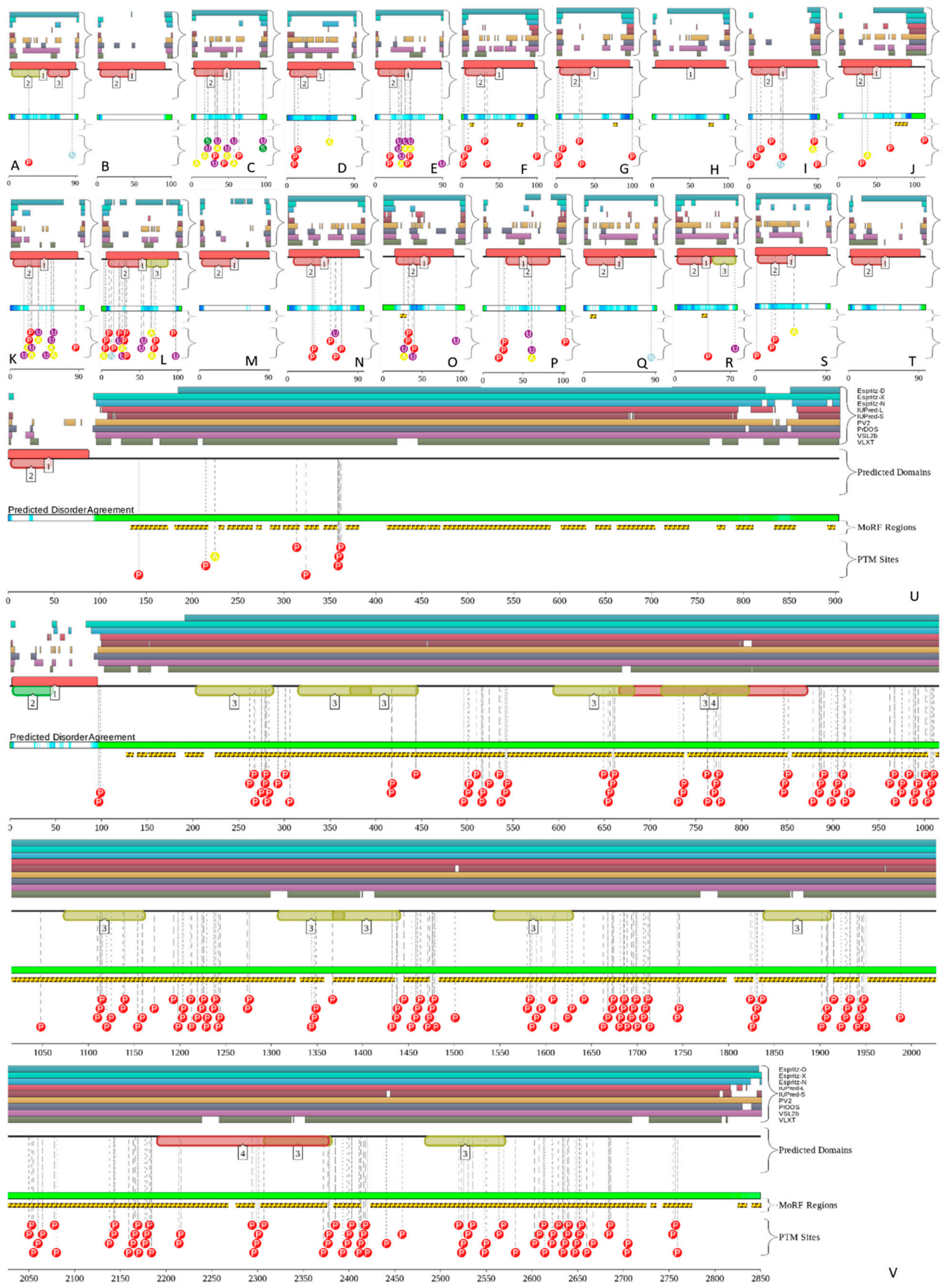

Figure 10. $\mathrm{D}^{2} \mathrm{P}^{2}$-generated functional disorder profiles of human S100 proteins. A. S100A1; B. S100A3; C. S100A4; D. S100A5; E. S100A6; F. S100A7; G. S100A7A; H. S100A7L2; I. S100A8; J. S100A9; K. S100A10; L. S100A11; M. S100A12; N. S100A13; O. S100A14; P. S100A16; Q. S100B; R. S100G; S. S100P; T. S100Z; U. S100A17; V. S100A18. All the keys are described in the legend to Figure 9.

With the exception for S100A12-ANXA5 complex representing a unique pair, generally both S100 proteins and annexins show remarkable cross-reactivity, where, for example, S100A6 forms functional 
complexes with ANXA2, ANXA6, and ANXA11, whereas S100A11 interacts with ANXA1, ANXA2, and ANXA6. On the other hand, ANXA2 is found in complexes with S100A4, S100A6, S100A10, and S100A11, whereas ANXA6 is shown to interact with S100A1, S100A6, S100A11, and S100B [1]. Such S100-annexin complexes can be formed on either a $\mathrm{Ca}^{2+}$-dependent or $\mathrm{Ca}^{2+}$-independent manner and have a multitude of functional roles, being involved in the differentiation of gonad cells, regulation of the organization of membranes and vesicles, appropriate disposition of membrane-associated proteins, such as ion channels and/or receptors, and are related to neurological disorders [1]. Importantly, there is a broad system of S100-annexin complexes. Some of these complexes are briefly considered below.

The S100A1-ANXA6 and S100B-ANXA6 complexes are found in the membranes of the sarcoplasmic reticulum, the sarcolemma, and transverse tubules in avian skeletal muscle cell, where they can be involved in the regulation of $\mathrm{Ca}^{2+}$ fluxes in skeletal muscle cells [151]. Formation of these complexes takes place at high $\mathrm{Ca}^{2+}$ concentrations [152] and is driven by the C-terminal half of ANXA6 and does not involve the C-terminal extension of either S100 protein [152,153].

S100A4 is a metastasis-associated protein that forms a complex with ANXA2 and formation of this complex induces angiogenesis [154]. Various functions of ANXA2 in membrane aggregation and endo- and exocytosis are regulated by $\mathrm{Ca}^{2+}$ binding, interaction with membrane, various PTMs, and interaction of its intrinsically disordered N-terminal domain (NTD, residues 2-33) with different proteins, including S100A4 and S100A10 [154,155]. Although both ANXA2-S100A4 and ANXA2-S100A10 complexes are heterotetramers, their formation is driven by rather different utilization of the intrinsically disordered NTD of ANXA2, where in the ANXA2-S100A10 complex, interaction is driven by residues 2-14 of ANXA2 binding to S100A10, whereas in ANXA2-S100A4 complex, the entire NTD is wrapped around the S100A4 dimer [155]. The S100A10-ANXA2 complex represents a heterotetramer $\left[(\mathrm{S} 100 \mathrm{~A} 10)_{2}-(\mathrm{ANXA} 2)_{2}\right]$, where $(\mathrm{S} 100 \mathrm{~A} 10)_{2}$ is located at the center of the complex, interconnecting two ANXA2 molecules. This complex can be found in a membrane fraction and is implicated in liposome aggregation in vitro and in endo- and exocytosis in vivo [156]. Formation of this complex is driven by the N-terminal residues (Val3, Ile6, Leu7, Leu10) of S100A10 [157,158]. As it follows from Figure 10K, these residues are a part of the N-terminal IDPR. Since S100A10 is the only S100 family members that is unable to bind to $\mathrm{Ca}^{2+}$ because of the mutation within its EF-hand motifs, formation of the S100A10-ANXA2 complex is regulated by the ANXA2 PTMs $[74,159,160]$. Because of its heterotetrameric nature, [(S100A10) ${ }_{2}-(\mathrm{ANXA2})_{2}$ ] was shown to link two different membranes [161]. However, it also can attain a geometry, where two ANXA2 molecules bind to the same membrane, and (S100A10) ${ }_{2}$ dimer is facing away from the membrane, creating a platform for interaction with other proteins [162]. In addition to membrane, [(S100A10) ${ }_{2}-(\mathrm{ANXA2})_{2}$ ] was shown to interact with multiple binding partners both inside and outside the cell, such as tissue-type plasminogen activator in the extracellular space [163], as well as various membrane proteins, such as potassium channels [164,165], serotonin 5-HT1B receptors [166], sodium channel [167], and transient receptor potential channels [168].

Malignant tumors are characterized by high expression levels of S100A6 and ANXA11, suggesting that these proteins are related to cancer biology and regulation of the cell cycle $[169,170]$. Formation of the S100A6-ANXA11 complex is $\mathrm{Ca}^{2+}$-dependent and involves interaction of the $\mathrm{N}$-terminal region of ANXA11 (residues 49-62) with S100A6 [171]. Figure 9J shows that although the $200 \mathrm{~N}$-terminal residues of ANXA11 are intrinsically disordered, this region contains two MoRFs (residues 39-49 and 143-212), one of which includes the aforementioned ANXA11 region engaged in the S100A6 binding. In addition to its role in cell cycle regulation and cancer development, the S100A6-ANXA11 complex can be engaged in triggering a cascade for sex determination via some cell stage-specific events [172].

The S100A10-ANXA1 complex can be found on the early endosomal membranes [173] and in the cornified envelope preparation of human keratinocytes [174]. Since this complex is formed in a $\mathrm{Ca}^{2+}$-dependent manner, it was suggested that it can be related to the regulation of some $\mathrm{Ca}^{2+}$-dependent cellular events [72]. Formation of this heterotetrameric complex is driven by interaction of the N-terminal region of ANXA1 with S100A10 [72,73]. Figure 9A demonstrates that the intrinsically disordered N-tail of ANXA1 contains a MoRF (residues 7-12), which potentially serves as binding 
site for S100A10. This is in a great agreement with the results of a focused study on the molecular mechanisms of the S100A10-ANXA1 complex formation, which showed that the N-terminal residues 1-13 of ANXA1 and the C-terminal residues 91-94 of S100A10 (which, according to Figure 10K is intrinsically disordered) are indispensable for the complex formation [73].

\section{Conclusions: Structure-Function Continuum of Annexins and S100 Proteins; Proteoforms Originating from Intrinsic Disorder and Structural Polymorphism as a Clue for Understanding the Multifunctionality and Binding Promiscuity}

Considered is this article are two large families of human $\mathrm{Ca}^{2+}$-binding protein that play crucial roles is a wide spectrum of cellular processes. Despite the fact that annexins and S100 proteins are rather structured, they are engaged in multiple interactions with large sets of unrelated proteins. We show here that multifunctionality and binding promiscuity of these proteins likely have their roots in intrinsic disorder phenomenon. In fact, all proteins in these families have variable levels intrinsic disorder, with some being rather substantial. This is an important observation, since IDPs and hybrid proteins containing ordered domains and IDPRs have found multiple functional applications of intrinsic disorder. This is directly related to the spatiotemporal structural organization of IDPs/IDPRs, which is known to be very complex and heterogeneous. In fact, looking at the structure of functional proteins, one can find there foldons (independent foldable units of a protein), inducible foldons (disordered regions that can fold at least in part due to the interaction with binding partners), morphing inducible foldons (disordered regions that can differently fold at binding to different binding partners), non-foldons (non-foldable protein regions), and semi-foldons (regions that are always in a semi-folded form) $[11,21,175]$. Furthermore, functionality of many ordered proteins depends on local unfolding, indicating that these proteins contains unfoldons (ordered regions that have to undergo an order-to-disorder transition to become functional) [176]. Obviously, because of such intricate mosaic-like structural "anatomy," IDPs/IDPRs are expected to have defined their distinctive molecular "physiology," with differently (dis)ordered structural elements possessing characteristic functions [22]. All this represents a foundation for multifunctionality of proteins and their ability to be involved in interaction with, regulation of, and be controlled by multiple structurally unrelated partners [22].

This multifarious, structurally and functionally heterogeneous organization of IDPs/IDPRs uniquely places them at the core of the structure-function continuum concept, where instead of the classical (but heavily oversimplified) "one gene-one protein-one structure-one function" view, the relationships between protein structure and function are described by the more convoluted "one gene-many proteins-many conformational ensembles-many-functions" model [22,177], which is based on the proteoform concept [178] introduced to explain an important observation that the complexity of a biological systems is mostly determined by its proteome size and not by the genome size [179]. In fact, the number of functionally different proteins is known to dramatically exceed the number of protein-encoding genes (e.g., human genomes is approaching 20,700 genes [180], but the actual number of functionally different proteins is in a range of a few million [181-185]). The increased size of the functional proteome over a corresponding genome is determined by multiple factors, ranging from the allelic variations (mutations) and various pre-translational mechanisms affecting genes (e.g., production of numerous mRNA variants by the alternative splicing and mRNA editing) to numerous chemical changes induced to proteins by various PTMs [181-185]. In fact, since PTMs can affect protein activity, folding, interactions, localization, stability, and turnover, they are crucial constituents of the protein structure-function continuum, where generation of the multiple proteoforms of a given protein by various mechanisms (including PTMs) defines the ability of a protein to have a multitude of structurally and functionally different states, proteoforms $[15,22,177,186,187]$. As a results, a single gene can efficiently encode for a set of distinct protein molecules, giving rise to the aforementioned proteoform concept [178]. Furthermore, in addition to the means increasing the chemical variability of a polypeptide chain, the protein structural diversity can be further increased by intrinsic disorder and functioning $[15,22,177,186]$. In fact, it was pointed out that even without 
AS, PTMs, or mutations, any protein, being a dynamic conformational ensemble, represents a set of basic (or intrinsic, or conformational) proteoforms; i.e., molecules with identical amino acid sequences but with different structures and, potentially, with different functions. Obviously, any mutated, modified, or alternatively spliced form of a protein (i.e., any member of the inducible (or modified) proteoforms) also exists as a structural ensemble and thereby represents a set of conformational proteoforms $[15,22,177,186]$. Finally, since protein function, interaction with specific partners, or placement inside the extremely crowded cellular environment can affect structural ensembles of basic and induced proteoforms, functionality per se can be considered as a factor generating functioning proteoforms $[15,22,177,186]$. In other words, because of all these factors, any given protein exists as a set of basic, induced, and functioning proteoforms $[15,22,177,186]$. It was also pointed out that combination of AS, PTMs, and intrinsic disorder represents an important means forthe promotion of the alternative, context-dependent states of gene regulatory networks, thereby serving as a critical tool for controlling of a broad range of cellular responses, including cell fate specification [188].

Let us consider now how all these concepts are applicable to the multifunctional annexins and S100 proteins. As it was discussed in this article, these proteins have ordered domains and IDPRs, thereby possessing foldons and non-foldons. Some of the IDPRs can fold at interaction with binding partners, thereby serving as an illustration of inducible foldons. Finally, at least for two annexins (ANXA1 and ANXA2) it was shown that calcium binding resulted in extrusion of their N-terminal head domains [117] that potentially can fold at interaction with binding partners (members of S100 family). Therefore, these head domains can be classified as unfoldons (they are expelled as a result of calcium binding and likely to become disordered) or inducible foldons (they partially fold at interaction with their binding partners), or even morphing inducible foldons (they might have different structures within parent annexin and in a complex with a partner). Since calcium binding results of structuration of neighboring regions, $\mathrm{Ca}^{2+}$-binding sites of both families might serve as examples of inducible foldons. All this shows that all annexins and S100 proteins can be considered as basic (or intrinsic, or conformational) proteoforms. Since members of these two calcium-binding families have multiple AS-generated isoforms and are heavily decorated by various PTMs, annexins and S100 proteins exist as inducible (or modified) proteoforms. Finally, formation of interfamily annexin-S100 complexes crucial for functionality of these proteins (with functions of annexin-S100 complexes being different from functions of their original components) serves as an illustrative example of functioning proteoforms. In other words, intrinsic disorder-based structure-function continuum based on the consideration of the corresponding basic, induced, and functioning proteoforms provides an important clue for understanding the molecular mechanisms of multifunctionality and binding promiscuity of human annexins and S100 proteins.

Supplementary Materials: Supplementary materials can be found at http://www.mdpi.com/1422-0067/21/16/ 5879/s1.

Author Contributions: J.W.- - conducted research, collected and analyzed literature data, and helped with the manuscript preparation; V.N.U.- conceived the idea, collected and analyzed literature data, conducted research, and wrote the manuscript. All authors have read and agreed to the published version of the manuscript.

Funding: This research received no external funding.

Conflicts of Interest: The authors declare no conflict of interest.

\section{References}

1. Miwa, N.; Uebi, T.; Kawamura, S. S100-annexin complexes-biology of conditional association. FEBS J. 2008, 275, 4945-4955. [CrossRef] [PubMed]

2. Nockolds, C.E.; Kretsinger, R.H.; Coffee, C.J.; Bradshaw, R.A. Structure of a calcium-binding carp myogen. Proc. Natl. Acad. Sci. USA 1972, 69, 581-584. [CrossRef] [PubMed] 
3. Raynal, P.; Pollard, H.B. Annexins: The problem of assessing the biological role for a gene family of multifunctional calcium- and phospholipid-binding proteins. Biochim. Biophys. Acta 1994, 1197, 63-93. [CrossRef]

4. Gerke, V.; Moss, S.E. Annexins: From structure to function. Physiol. Rev. 2002, 82, 331-371. [CrossRef]

5. Dunker, A.K.; Lawson, J.D.; Brown, C.J.; Williams, R.M.; Romero, P.; Oh, J.S.; Oldfield, C.J.; Campen, A.M.; Ratliff, C.M.; Hipps, K.W.; et al. Intrinsically disordered protein. J. Mol. Graph. Model. 2001, 19, $26-59$. [CrossRef]

6. Wright, P.E.; Dyson, H.J. Intrinsically unstructured proteins: Re-assessing the protein structure-function paradigm. J. Mol. Biol. 1999, 293, 321-331. [CrossRef]

7. Uversky, V.N.; Gillespie, J.R.; Fink, A.L. Why are "natively unfolded" proteins unstructured under physiologic conditions? Proteins 2000, 41, 415-427. [CrossRef]

8. Tompa, P. Intrinsically unstructured proteins. Trends Biochem. Sci. 2002, 27, 527-533. [CrossRef]

9. Uversky, V.N.; Dunker, A.K. Understanding protein non-folding. Biochim. Biophys. Acta 2010, 1804, 1231-1264. [CrossRef]

10. Tompa, P. Intrinsically disordered proteins: A 10-year recap. Trends Biochem. Sci. 2012, 37, 509-516. [CrossRef]

11. Uversky, V.N. A decade and a half of protein intrinsic disorder: Biology still waits for physics. Protein Sci. 2013, 22, 693-724. [CrossRef] [PubMed]

12. van der Lee, R.; Buljan, M.; Lang, B.; Weatheritt, R.J.; Daughdrill, G.W.; Dunker, A.K.; Fuxreiter, M.; Gough, J.; Gsponer, J.; Jones, D.T.; et al. Classification of intrinsically disordered regions and proteins. Chem. Rev. 2014, 114, 6589-6631. [CrossRef] [PubMed]

13. Habchi, J.; Tompa, P.; Longhi, S.; Uversky, V.N. Introducing protein intrinsic disorder. Chem. Rev. 2014, 114, 6561-6588. [CrossRef] [PubMed]

14. Oldfield, C.J.; Dunker, A.K. Intrinsically disordered proteins and intrinsically disordered protein regions. Annu. Rev. Biochem. 2014, 83, 553-584. [CrossRef]

15. Uversky, V.N. Dancing protein clouds: The strange biology and chaotic physics of intrinsically disordered proteins. J. Biol. Chem. 2016, 291, 6681-6688. [CrossRef]

16. Dunker, A.K.; Brown, C.J.; Lawson, J.D.; Iakoucheva, L.M.; Obradovic, Z. Intrinsic disorder and protein function. Biochemistry 2002, 41, 6573-6582. [CrossRef]

17. Dunker, A.K.; Brown, C.J.; Obradovic, Z. Identification and functions of usefully disordered proteins. Adv. Protein Chem. 2002, 62, 25-49.

18. Uversky, V.N. Natively unfolded proteins: A point where biology waits for physics. Protein Sci. 2002, 11, 739-756. [CrossRef]

19. Uversky, V.N. What does it mean to be natively unfolded? Eur. J. Biochem. 2002, 269, 2-12. [CrossRef]

20. Uversky, V.N. Protein folding revisited. A polypeptide chain at the folding-misfolding-nonfolding cross-roads: Which way to go? Cell. Mol. Life Sci. 2003, 60, 1852-1871. [CrossRef]

21. Uversky, V.N. Unusual biophysics of intrinsically disordered proteins. Biochim. Biophys. Acta 2013, 1834, 932-951. [CrossRef] [PubMed]

22. Uversky, V.N. Functional roles of transiently and intrinsically disordered regions within proteins. FEBS J. 2015, 282, 1182-1189. [CrossRef]

23. Iakoucheva, L.M.; Radivojac, P.; Brown, C.J.; O'Connor, T.R.; Sikes, J.G.; Obradovic, Z.; Dunker, A.K. The importance of intrinsic disorder for protein phosphorylation. Nucleic. Acids Res. 2004, 32, 1037-1049. [CrossRef] [PubMed]

24. Pejaver, V.; Hsu, W.L.; Xin, F.; Dunker, A.K.; Uversky, V.N.; Radivojac, P. The structural and functional signatures of proteins that undergo multiple events of post-translational modification. Protein Sci. 2014, 23, 1077-1093. [CrossRef] [PubMed]

25. Romero, P.R.; Zaidi, S.; Fang, Y.Y.; Uversky, V.N.; Radivojac, P.; Oldfield, C.J.; Cortese, M.S.; Sickmeier, M.; LeGall, T.; Obradovic, Z.; et al. Alternative splicing in concert with protein intrinsic disorder enables increased functional diversity in multicellular organisms. Proc. Natl. Acad. Sci. USA 2006, 103, 8390-8395. [CrossRef]

26. Buljan, M.; Chalancon, G.; Dunker, A.K.; Bateman, A.; Balaji, S.; Fuxreiter, M.; Babu, M.M. Alternative splicing of intrinsically disordered regions and rewiring of protein interactions. Curr. Opin. Struct. Biol. 2013, 23, 443-450. [CrossRef] 
27. Buljan, M.; Chalancon, G.; Eustermann, S.; Wagner, G.P.; Fuxreiter, M.; Bateman, A.; Babu, M.M. Tissue-specific splicing of disordered segments that embed binding motifs rewires protein interaction networks. Mol. Cell. 2012, 46, 871-883. [CrossRef]

28. Uversky, V.N.; Oldfield, C.J.; Dunker, A.K. Intrinsically disordered proteins in human diseases: Introducing the D2 concept. Annu. Rev. Biophys. 2008, 37, 215-246. [CrossRef]

29. Uversky, V.N.; Dave, V.; Iakoucheva, L.M.; Malaney, P.; Metallo, S.J.; Pathak, R.R.; Joerger, A.C. Pathological unfoldomics of uncontrolled chaos: Intrinsically disordered proteins and human diseases. Chem. Rev. 2014, 114, 6844-6879. [CrossRef]

30. Uversky, V.N. Wrecked regulation of intrinsically disordered proteins in diseases: Pathogenicity of deregulated regulators. Front. Mol. Biosci. 2014, 1, 6. [CrossRef]

31. Engelkamp, D.; Schafer, B.W.; Mattei, M.G.; Erne, P.; Heizmann, C.W. Six S100 genes are clustered on human chromosome 1q21: Identification of two genes coding for the two previously unreported calcium-binding proteins S100D and S100E. Proc. Natl. Acad. Sci. USA 1993, 90, 6547-6551. [CrossRef] [PubMed]

32. Schafer, B.W.; Wicki, R.; Engelkamp, D.; Mattei, M.G.; Heizmann, C.W. Isolation of a YAC clone covering a cluster of nine S100 genes on human chromosome 1q21: Rationale for a new nomenclature of the S100 calcium-binding protein family. Genomics 1995, 25, 638-643. [CrossRef]

33. Marenholz, I.; Lovering, R.C.; Heizmann, C.W. An update of the S100 nomenclature. Biochim. Biophys. Acta 2006, 1763, 1282-1283. [CrossRef] [PubMed]

34. Donato, R.; Sorci, G.; Riuzzi, F.; Arcuri, C.; Bianchi, R.; Brozzi, F.; Tubaro, C.; Giambanco, I. S100B's double life: Intracellular regulator and extracellular signal. Biochim. Biophys. Acta 2009, 1793, 1008-1022. [CrossRef]

35. Heizmann, C.W.; Fritz, G.; Schafer, B.W. S100 proteins: Structure, functions and pathology. Front. Biosci. 2002, 7, d1356-d1368. [PubMed]

36. Heizmann, C.W.; Cox, J.A. New perspectives on $\mathrm{S} 100$ proteins: A multi-functional $\mathrm{Ca}(2+)-, \mathrm{Zn}(2+)-$ and $\mathrm{Cu}(2+)$-binding protein family. Biometals 1998, 11, 383-397. [CrossRef]

37. Donato, R. S100: A multigenic family of calcium-modulated proteins of the EF-hand type with intracellular and extracellular functional roles. Int. J. Biochem. Cell. Biol. 2001, 33, 637-668. [CrossRef]

38. Marenholz, I.; Heizmann, C.W.; Fritz, G. S100 proteins in mouse and man: From evolution to function and pathology (including an update of the nomenclature). Biochem. Biophys. Res. Commun. 2004, 322, 1111-1122. [CrossRef]

39. Santamaria-Kisiel, L.; Rintala-Dempsey, A.C.; Shaw, G.S. Calcium-dependent and -independent interactions of the S100 protein family. Biochem. J. 2006, 396, 201-214. [CrossRef]

40. Schaub, M.C.; Heizmann, C.W. Calcium, troponin, calmodulin, S100 proteins: From myocardial basics to new therapeutic strategies. Biochem. Biophys. Res. Commun. 2008, 369, 247-264. [CrossRef]

41. Permyakov, E. Metalloproteomics; John Wiley \& Sons, Inc.: Hoboken, NJ, USA, 2009; p. 786.

42. Moroz, O.V.; Wilson, K.S.; Bronstein, I.B. The role of zinc in the S100 proteins: Insights from the X-ray structures. Amino Acids 2010, 41, 761-772. [CrossRef] [PubMed]

43. Gifford, J.L.; Walsh, M.P.; Vogel, H.J. Structures and metal-ion-binding properties of the $\mathrm{Ca}^{2+}$-binding helix-loop-helix EF-hand motifs. Biochem. J. 2007, 405, 199-221. [CrossRef] [PubMed]

44. Calderone, V.; Fragai, M.; Luchinat, C. Reviewing the crystal structure of S100Z and other members of the S100 family: Implications in calcium-regulated quaternary structure. Methods Mol. Biol. 2019, 1929, 487-499. [CrossRef] [PubMed]

45. Winningham-Major, F.; Staecker, J.L.; Barger, S.W.; Coats, S.; Van Eldik, L.J. Neurite extension and neuronal survival activities of recombinant S100 beta proteins that differ in the content and position of cysteine residues. J. Cell. Biol. 1989, 109, 3063-3071. [CrossRef]

46. Heizmann, C.W.; Ackermann, G.E.; Galichet, A. Pathologies involving the S100 proteins and RAGE. Subcell. Biochem. 2007, 45, 93-138.

47. Edgeworth, J.; Freemont, P.; Hogg, N. Ionomycin-regulated phosphorylation of the myeloid calcium-binding protein p14. Nature 1989, 342, 189-192. [CrossRef]

48. Guignard, F.; Mauel, J.; Markert, M. Phosphorylation of myeloid-related proteins MRP-14 and MRP-8 during human neutrophil activation. Eur. J. Biochem. 1996, 241, 265-271. [CrossRef]

49. Siegenthaler, G.; Roulin, K.; Chatellard-Gruaz, D.; Hotz, R.; Saurat, J.H.; Hellman, U.; Hagens, G. A heterocomplex formed by the calcium-binding proteins MRP8 (S100A8) and MRP14 (S100A9) binds unsaturated fatty acids with high affinity. J. Biol. Chem. 1997, 272, 9371-9377. [CrossRef] 
50. Kerkhoff, C.; Klempt, M.; Sorg, C. Novel insights into structure and function of MRP8 (S100A8) and MRP14 (S100A9). Biochim. Biophys. Acta 1998, 1448, 200-211. [CrossRef]

51. Heizmann, C.W. The multifunctional S100 protein family. Methods Mol. Biol. 2002, 172, 69-80. [CrossRef]

52. Donato, R. Functional roles of $\mathrm{S} 100$ proteins, calcium-binding proteins of the EF-hand type. Biochim. Biophys. Acta 1999, 1450, 191-231. [CrossRef]

53. Smith, S.P.; Shaw, G.S. A change-in-hand mechanism for S100 signalling. Biochem. Cell. Biol. 1998, 76, 324-333. [CrossRef] [PubMed]

54. Schafer, B.W.; Heizmann, C.W. The S100 family of EF-hand calcium-binding proteins: Functions and pathology. Trends Biochem. Sci. 1996, 21, 134-140. [CrossRef]

55. Zimmer, D.B.; Cornwall, E.H.; Landar, A.; Song, W. The S100 protein family: History, function, and expression. Brain Res. Bull. 1995, 37, 417-429. [CrossRef]

56. Kligman, D.; Hilt, D.C. The S100 protein family. Trends Biochem. Sci. 1988, 13, 437-443. [CrossRef]

57. Heizmann, C.W. S100 proteins: Diagnostic and prognostic biomarkers in laboratory medicine. Biochim. Biophys. Acta Mol. Cell. Res. 2019, 1866, 1197-1206. [CrossRef]

58. Griffin, W.S.; Stanley, L.C.; Ling, C.; White, L.; MacLeod, V.; Perrot, L.J.; White, C.L., 3rd; Araoz, C. Brain interleukin 1 and S-100 immunoreactivity are elevated in Down syndrome and Alzheimer disease. Proc. Natl. Acad. Sci. USA 1989, 86, 7611-7615. [CrossRef]

59. Cross, S.S.; Hamdy, F.C.; Deloulme, J.C.; Rehman, I. Expression of S100 proteins in normal human tissues and common cancers using tissue microarrays: S100A6, S100A8, S100A9 and S100A11 are all overexpressed in common cancers. Histopathology 2005, 46, 256-269. [CrossRef]

60. Stanley, L.C.; Mrak, R.E.; Woody, R.C.; Perrot, L.J.; Zhang, S.; Marshak, D.R.; Nelson, S.J.; Griffin, W.S. Glial cytokines as neuropathogenic factors in HIV infection: Pathogenic similarities to Alzheimer's disease. J. Neuropathol. Exp. Neurol. 1994, 53, 231-238. [CrossRef]

61. Austermann, J.; Spiekermann, C.; Roth, J. S100 proteins in rheumatic diseases. Nat. Rev. Rheumatol. 2018, 14, 528-541. [CrossRef]

62. Bresnick, A.R. S100 proteins as therapeutic targets. Biophys. Rev. 2018, 10, 1617-1629. [CrossRef] [PubMed]

63. Heizmann, C.W. Ca(2+)-binding proteins of the EF-hand superfamily: Diagnostic and prognostic biomarkers and novel therapeutic targets. Methods Mol. Biol. 2019, 1929, 157-186. [CrossRef] [PubMed]

64. Austermann, J.; Zenker, S.; Roth, J. S100-alarmins: Potential therapeutic targets for arthritis. Expert Opin. Ther. Targets 2017, 21, 739-751. [CrossRef] [PubMed]

65. Weng, X.; Luecke, H.; Song, I.S.; Kang, D.S.; Kim, S.H.; Huber, R. Crystal structure of human annexin I at 2.5 A resolution. Protein Sci. 1993, 2, 448-458. [CrossRef] [PubMed]

66. Smith, P.D.; Moss, S.E. Structural evolution of the annexin supergene family. Trends Genet. 1994, 10, $241-246$. [CrossRef]

67. Freye-Minks, C.; Kretsinger, R.H.; Creutz, C.E. Structural and dynamic changes in human annexin VI induced by a phosphorylation-mimicking mutation, T356D. Biochemistry 2003, 42, 620-630. [CrossRef]

68. Avila-Sakar, A.J.; Kretsinger, R.H.; Creutz, C.E. Membrane-bound 3D structures reveal the intrinsic flexibility of annexin VI. J. Struct. Biol. 2000, 130, 54-62. [CrossRef]

69. Shatsky, M.; Nussinov, R.; Wolfson, H.J. A method for simultaneous alignment of multiple protein structures. Proteins 2004, 56, 143-156. [CrossRef]

70. Humphrey, W.; Dalke, A.; Schulten, K. VMD: Visual molecular dynamics. J. Mol. Graph. 1996, 14, 33-38. [CrossRef]

71. Hofmann, A.; Raguenes-Nicol, C.; Favier-Perron, B.; Mesonero, J.; Huber, R.; Russo-Marie, F.; Lewit-Bentley, A. The annexin A3-membrane interaction is modulated by an N-terminal tryptophan. Biochemistry 2000, 39, 7712-7721. [CrossRef]

72. Mailliard, W.S.; Haigler, H.T.; Schlaepfer, D.D. Calcium-dependent binding of S100C to the N-terminal domain of annexin I. J. Biol. Chem. 1996, 271, 719-725. [CrossRef] [PubMed]

73. Seemann, J.; Weber, K.; Gerke, V. Structural requirements for annexin I-S100C complex-formation. Biochem. J. 1996, 319 Pt 1, 123-129. [CrossRef]

74. Becker, T.; Weber, K.; Johnsson, N. Protein-protein recognition via short amphiphilic helices; a mutational analysis of the binding site of annexin II for p11. EMBO J. 1990, 9, 4207-4213. [CrossRef] [PubMed] 
75. Moore, P.B.; Kraus-Friedmann, N.; Dedman, J.R. Unique calcium-dependent hydrophobic binding proteins: Possible independent mediators of intracellular calcium distinct from calmodulin. J. Cell. Sci. 1984, 72 , 121-133. [PubMed]

76. Glenney, J.R., Jr.; Tack, B.; Powell, M.A. Calpactins: Two distinct Ca++-regulated phospholipid- and actin-binding proteins isolated from lung and placenta. J. Cell. Biol. 1987, 104, 503-511. [CrossRef] [PubMed]

77. Creutz, C.E.; Zaks, W.J.; Hamman, H.C.; Crane, S.; Martin, W.H.; Gould, K.L.; Oddie, K.M.; Parsons, S.J. Identification of chromaffin granule-binding proteins. Relationship of the chromobindins to calelectrin, synhibin, and the tyrosine kinase substrates p35 and p36. J. Biol. Chem. 1987, 262, 1860-1868.

78. Flower, R.J. Background and discovery of lipocortins. Agents Actions 1986, 17, 255-262. [CrossRef]

79. Creutz, C.E.; Pazoles, C.J.; Pollard, H.B. Identification and purification of an adrenal medullary protein (synexin) that causes calcium-dependent aggregation of isolated chromaffin granules. J. Biol. Chem. 1978, 253, 2858-2866.

80. Crumpton, M.J.; Dedman, J.R. Protein terminology tangle. Nature 1990, 345, 212. [CrossRef]

81. Monastyrskaya, K.; Babiychuk, E.B.; Hostettler, A.; Rescher, U.; Draeger, A. Annexins as intracellular calcium sensors. Cell Calcium 2007, 41, 207-219. [CrossRef]

82. Eberhard, D.A.; Karns, L.R.; VandenBerg, S.R.; Creutz, C.E. Control of the nuclear-cytoplasmic partitioning of annexin II by a nuclear export signal and by p11 binding. J. Cell Sci. 2001, 114, 3155-3166. [PubMed]

83. Merrifield, C.J.; Rescher, U.; Almers, W.; Proust, J.; Gerke, V.; Sechi, A.S.; Moss, S.E. Annexin 2 has an essential role in actin-based macropinocytic rocketing. Curr. Biol. 2001, 11, 1136-1141. [CrossRef]

84. Rescher, U.; Zobiack, N.; Gerke, V. Intact $\mathrm{Ca}(2+)$-binding sites are required for targeting of annexin 1 to endosomal membranes in living HeLa cells. J. Cell Sci. 2000, 113 Pt 22, 3931-3938.

85. Langen, R.; Isas, J.M.; Hubbell, W.L.; Haigler, H.T. A transmembrane form of annexin XII detected by site-directed spin labeling. Proc. Natl. Acad. Sci. USA 1998, 95, 14060-14065. [CrossRef] [PubMed]

86. Langen, R.; Isas, J.M.; Luecke, H.; Haigler, H.T.; Hubbell, W.L. Membrane-mediated assembly of annexins studied by site-directed spin labeling. J. Biol. Chem. 1998, 273, 22453-22457. [CrossRef] [PubMed]

87. Sokolov, Y.; Mailliard, W.S.; Tranngo, N.; Isas, M.; Luecke, H.; Haigler, H.T.; Hall, J.E. Annexins V and XII alter the properties of planar lipid bilayers seen by conductance probes. J. Gen. Physiol. 2000, 115, 571-582. [CrossRef] [PubMed]

88. Gerke, V.; Creutz, C.E.; Moss, S.E. Annexins: Linking $\mathrm{Ca}^{2+}$ signalling to membrane dynamics. Nat. Rev. Mol. Cell Biol. 2005, 6, 449-461. [CrossRef] [PubMed]

89. van Genderen, H.O.; Kenis, H.; Hofstra, L.; Narula, J.; Reutelingsperger, C.P. Extracellular annexin A5: Functions of phosphatidylserine-binding and two-dimensional crystallization. Biochim. Biophys. Acta 2008, 1783, 953-963. [CrossRef]

90. Hayes, M.J.; Longbottom, R.E.; Evans, M.A.; Moss, S.E. Annexinopathies. Subcell. Biochem. 2007, 45, 1-28.

91. Bruschi, M.; Petretto, A.; Vaglio, A.; Santucci, L.; Candiano, G.; Ghiggeri, G.M. Annexin A1 and autoimmunity: From basic science to clinical applications. Int. J. Mol. Sci. 2018, 19, 1348. [CrossRef]

92. Perucci, L.O.; Carneiro, F.S.; Ferreira, C.N.; Sugimoto, M.A.; Soriani, F.M.; Martins, G.G.; Lima, K.M.; Guimaraes, F.L.; Teixeira, A.L.; Dusse, L.M.; et al. Annexin A1 is increased in the plasma of preeclamptic women. PLoS ONE 2015, 10, e0138475. [CrossRef] [PubMed]

93. Shao, G.; Zhou, H.; Zhang, Q.; Jin, Y.; Fu, C. Advancements of annexin A1 in inflammation and tumorigenesis. Onco Targets Ther. 2019, 12, 3245-3254. [CrossRef] [PubMed]

94. Cristante, E.; McArthur, S.; Mauro, C.; Maggioli, E.; Romero, I.A.; Wylezinska-Arridge, M.; Couraud, P.O.; Lopez-Tremoleda, J.; Christian, H.C.; Weksler, B.B.; et al. Identification of an essential endogenous regulator of blood-brain barrier integrity, and its pathological and therapeutic implications. Proc. Natl. Acad. Sci. USA 2013, 110, 832-841. [CrossRef] [PubMed]

95. Sheikh, M.H.; Solito, E. Annexin A1: Uncovering the many talents of an old protein. Int. J. Mol. Sci. 2018, 19, 1045. [CrossRef]

96. Hitchcock, J.K.; Katz, A.A.; Schafer, G. Dynamic reciprocity: The role of annexin A2 in tissue integrity. J. Cell Commun. Signal. 2014, 8, 125-133. [CrossRef]

97. Canas, F.; Simonin, L.; Couturaud, F.; Renaudineau, Y. Annexin A2 autoantibodies in thrombosis and autoimmune diseases. Thromb. Res. 2015, 135, 226-230. [CrossRef]

98. Sharma, M.C. Annexin A2 (ANX A2): An emerging biomarker and potential therapeutic target for aggressive cancers. Int. J. Cancer 2019, 144, 2074-2081. [CrossRef] 
99. Xu, X.H.; Pan, W.; Kang, L.H.; Feng, H.; Song, Y.Q. Association of annexin A2 with cancer development (Review). Oncol. Rep. 2015, 33, 2121-2128. [CrossRef]

100. Li, J.; Zhou, T.; Liu, L.; Ju, Y.C.; Chen, Y.T.; Tan, Z.R.; Wang, J. The regulatory role of Annexin 3 in a nude mouse bearing a subcutaneous xenograft of MDA-MB-231 human breast carcinoma. Pathol. Res. Pract. 2018, 214, 1719-1725. [CrossRef]

101. Tong, M.; Fung, T.M.; Luk, S.T.; Ng, K.Y.; Lee, T.K.; Lin, C.H.; Yam, J.W.; Chan, K.W.; Ng, F.; Zheng, B.J.; et al. ANXA3/JNK signaling promotes self-renewal and tumor growth, and its blockade provides a therapeutic target for hepatocellular carcinoma. Stem. Cell Rep. 2015, 5, 45-59. [CrossRef]

102. Pan, Q.Z.; Pan, K.; Wang, Q.J.; Weng, D.S.; Zhao, J.J.; Zheng, H.X.; Zhang, X.F.; Jiang, S.S.; Lv, L.; Tang, Y.; et al. Annexin A3 as a potential target for immunotherapy of liver cancer stem-like cells. Stem Cells 2015, 33, 354-366. [CrossRef] [PubMed]

103. Pan, Q.Z.; Pan, K.; Weng, D.S.; Zhao, J.J.; Zhang, X.F.; Wang, D.D.; Lv, L.; Jiang, S.S.; Zheng, H.X.; Xia, J.C. Annexin A3 promotes tumorigenesis and resistance to chemotherapy in hepatocellular carcinoma. Mol. Carcinog. 2015, 54, 598-607. [CrossRef] [PubMed]

104. de la Cuesta, F.; Alvarez-Llamas, G.; Maroto, A.S.; Donado, A.; Zubiri, I.; Posada, M.; Padial, L.R.; Pinto, A.G.; Barderas, M.G.; Vivanco, F. A proteomic focus on the alterations occurring at the human atherosclerotic coronary intima. Mol. Cell. Proteom. 2011, 10, M110-003517. [CrossRef] [PubMed]

105. Pogosian, G.G.; Mikaelian, M.V.; Avagian, A.; Gasparian, V.K. The annexin 5 in serums of pregnant women and patients with particular types of cancer. Klin. Lab. Diagn. 2014, 4, 14-17.

106. Emanuel, V.L.; Mnuskina, M.M.; Smirnov, A.V.; Panina, I.; Rumiantsev, A.; Vasina, E.; Vasina, L.B. Annexin-5 as a biochemical marker of early vascular disorders under chronic disease of kidneys. Klin. Lab. Diagn. 2013, 4, 9-10.

107. Burkhard, F.C.; Monastyrskaya, K.; Studer, U.E.; Draeger, A. Smooth muscle membrane organization in the normal and dysfunctional human urinary bladder: A structural analysis. Neurourol. Urodyn. 2005, 24, 128-135. [CrossRef]

108. Srivastava, M.; Montagna, C.; Leighton, X.; Glasman, M.; Naga, S.; Eidelman, O.; Ried, T.; Pollard, H.B. Haploinsufficiency of Anx7 tumor suppressor gene and consequent genomic instability promotes tumorigenesis in the Anx7(+/-) mouse. Proc. Natl. Acad. Sci. USA 2003, 100, 14287-14292. [CrossRef]

109. Lang, F.; Qadri, S.M. Mechanisms and significance of eryptosis, the suicidal death of erythrocytes. Blood Purif. 2012, 33, 125-130. [CrossRef]

110. Rossetti, S.; Bshara, W.; Reiners, J.A.; Corlazzoli, F.; Miller, A.; Sacchi, N. Harnessing 3D models of mammary epithelial morphogenesis: An off the beaten path approach to identify candidate biomarkers of early stage breast cancer. Cancer Lett. 2016, 380, 375-383. [CrossRef]

111. Calderon-Gonzalez, K.G.; Valero Rustarazo, M.L.; Labra-Barrios, M.L.; Bazan-Mendez, C.I.; Tavera-Tapia, A.; Herrera-Aguirre, M.E.; Sanchez del Pino, M.M.; Gallegos-Perez, J.L.; Gonzalez-Marquez, H.; Hernandez-Hernandez, J.M.; et al. Determination of the protein expression profiles of breast cancer cell lines by quantitative proteomics using iTRAQ labelling and tandem mass spectrometry. J. Proteom. 2015, 124, 50-78. [CrossRef]

112. Salom, C.; Alvarez-Teijeiro, S.; Fernandez, M.P.; Morgan, R.O.; Allonca, E.; Vallina, A.; Lorz, C.; de Villalain, L.; Fernandez-Garcia, M.S.; Rodrigo, J.P.; et al. Frequent alteration of annexin A9 and A10 in HPV-negative head and neck squamous cell carcinomas: Correlation with the histopathological differentiation grade. J. Clin. Med. 2019, 8, 229. [CrossRef] [PubMed]

113. Wang, J.; Guo, C.; Liu, S.; Qi, H.; Yin, Y.; Liang, R.; Sun, M.Z.; Greenaway, F.T. Annexin A11 in disease. Clin. Chim. Acta 2014, 431, 164-168. [CrossRef] [PubMed]

114. Benjachat, T.; Tongyoo, P.; Tantivitayakul, P.; Somparn, P.; Hirankarn, N.; Prom-On, S.; Pisitkun, P.; Leelahavanichkul, A.; Avihingsanon, Y.; Townamchai, N. Biomarkers for refractory lupus nephritis: A microarray study of kidney tissue. Int. J. Mol. Sci. 2015, 16, 14276-14290. [CrossRef]

115. Orchard, S.; Ammari, M.; Aranda, B.; Breuza, L.; Briganti, L.; Broackes-Carter, F.; Campbell, N.H.; Chavali, G.; Chen, C.; del-Toro, N.; et al. The MIntAct project-IntAct as a common curation platform for 11 molecular interaction databases. Nucleic Acids Res. 2014, 42, D358-D363. [CrossRef]

116. Szklarczyk, D.; Franceschini, A.; Kuhn, M.; Simonovic, M.; Roth, A.; Minguez, P.; Doerks, T.; Stark, M.; Muller, J.; Bork, P.; et al. The string database in 2011: Functional interaction networks of proteins, globally integrated and scored. Nucleic Acids Res. 2011, 39, D561-D568. [CrossRef] [PubMed] 
117. Rintala-Dempsey, A.C.; Rezvanpour, A.; Shaw, G.S. S100-annexin complexes-structural insights. FEBS J. 2008, 275, 4956-4966. [CrossRef] [PubMed]

118. Lewit-Bentley, A.; Rety, S.; Sopkova-de Oliveira Santos, J.; Gerke, V. S100-annexin complexes: Some insights from structural studies. Cell Biol. Int. 2000, 24, 799-802. [CrossRef]

119. Dyson, H.J.; Wright, P.E. Coupling of folding and binding for unstructured proteins. Curr. Opin. Struct. Biol. 2002, 12, 54-60. [CrossRef]

120. Iakoucheva, L.M.; Brown, C.J.; Lawson, J.D.; Obradovic, Z.; Dunker, A.K. Intrinsic disorder in cell-signaling and cancer-associated proteins. J. Mol. Biol. 2002, 323, 573-584. [CrossRef]

121. Dyson, H.J.; Wright, P.E. Intrinsically unstructured proteins and their functions. Nat. Rev. Mol. Cell Biol. 2005, 6, 197-208. [CrossRef]

122. Fink, A.L. Natively unfolded proteins. Curr. Opin. Struct. Biol. 2005, 15, 35-41. [CrossRef] [PubMed]

123. Dunker, A.K.; Cortese, M.S.; Romero, P.; Iakoucheva, L.M.; Uversky, V.N. Flexible nets: The roles of intrinsic disorder in protein interaction networks. FEBS J. 2005, 272, 5129-5148. [CrossRef] [PubMed]

124. Uversky, V.N.; Oldfield, C.J.; Dunker, A.K. Showing your ID: Intrinsic disorder as an ID for recognition, regulation and cell signaling. J. Mol. Recognit. 2005, 18, 343-384. [CrossRef] [PubMed]

125. Dunker, A.K.; Silman, I.; Uversky, V.N.; Sussman, J.L. Function and structure of inherently disordered proteins. Curr. Opin. Struct. Biol. 2008, 18, 756-764. [CrossRef] [PubMed]

126. Uversky, V.N.; Dunker, A.K. Biochemistry. Controlled chaos. Science 2008, 322, 1340-1341. [CrossRef]

127. Tompa, P.; Fuxreiter, M.; Oldfield, C.J.; Simon, I.; Dunker, A.K.; Uversky, V.N. Close encounters of the third kind: Disordered domains and the interactions of proteins. Bioessays 2009, 31, 328-335. [CrossRef]

128. Dunker, A.K.; Uversky, V.N. Signal transduction via unstructured protein conduits. Nat. Chem. Biol. 2008, 4, 229-230. [CrossRef]

129. Tompa, P.; Fuxreiter, M. Fuzzy complexes: Polymorphism and structural disorder in protein-protein interactions. Trends Biochem. Sci. 2008, 33, 2-8. [CrossRef]

130. Oldfield, C.J.; Meng, J.; Yang, J.Y.; Yang, M.Q.; Uversky, V.N.; Dunker, A.K. Flexible nets: Disorder and induced fit in the associations of p53 and 14-3-3 with their partners. BMC Genom. 2008, 9 (Suppl. 1), S1. [CrossRef]

131. Bertini, I.; Das Gupta, S.; Hu, X.; Karavelas, T.; Luchinat, C.; Parigi, G.; Yuan, J. Solution structure and dynamics of S100A5 in the apo and $\mathrm{Ca}^{2+}$-bound states. J. Biol. Inorg. Chem. 2009, 14, 1097-1107. [CrossRef]

132. Malik, S.; Revington, M.; Smith, S.P.; Shaw, G.S. Analysis of the structure of human apo-S100B at low temperature indicates a unimodal conformational distribution is adopted by calcium-free S100 proteins. Proteins 2008, 73, 28-42. [CrossRef]

133. Skelton, N.J.; Kordel, J.; Chazin, W.J. Determination of the solution structure of Apo calbindin D9k by NMR spectroscopy. J. Mol. Biol. 1995, 249, 441-462. [CrossRef] [PubMed]

134. Dutta, K.; Cox, C.J.; Basavappa, R.; Pascal, S.M. 15N relaxation studies of Apo-Mts1: A dynamic S100 protein. Biochemistry 2008, 47, 7637-7647. [CrossRef] [PubMed]

135. Obradovic, Z.; Peng, K.; Vucetic, S.; Radivojac, P.; Dunker, A.K. Exploiting heterogeneous sequence properties improves prediction of protein disorder. Proteins Struct. Funct. Bioinform. 2005, 61, 176-182. [CrossRef] [PubMed]

136. Peng, K.; Radivojac, P.; Vucetic, S.; Dunker, A.K.; Obradovic, Z. Length-dependent prediction of protein intrinsic disorder. BMC Bioinform. 2006, 7, 208. [CrossRef] [PubMed]

137. Permyakov, S.E.; Ismailov, R.G.; Xue, B.; Denesyuk, A.I.; Uversky, V.N.; Permyakov, E.A. Intrinsic disorder in S100 proteins. Mol. Biosyst. 2011, 7, 2164-2180. [CrossRef]

138. Romero, P.; Obradovic, Z.; Li, X.; Garner, E.C.; Brown, C.J.; Dunker, A.K. Sequence complexity of disordered protein. Proteins Struct. Funct. Bioinform. 2001, 42, 38-48. [CrossRef]

139. Rajagopalan, K.; Mooney, S.M.; Parekh, N.; Getzenberg, R.H.; Kulkarni, P. A majority of the cancer/testis antigens are intrinsically disordered proteins. J. Cell. Biochem. 2011, 112, 3256-3267. [CrossRef]

140. Hu, N.J.; Bradshaw, J.; Lauter, H.; Buckingham, J.; Solito, E.; Hofmann, A. Membrane-induced folding and structure of membrane-bound annexin A1 N-terminal peptides: Implications for annexin-induced membrane aggregation. Biophys. J. 2008, 94, 1773-1781. [CrossRef]

141. Yoon, M.K.; Park, S.H.; Won, H.S.; Na, D.S.; Lee, B.J. Solution structure and membrane-binding property of the N-terminal tail domain of human annexin I. FEBS Lett. 2000, 484, 241-245. [CrossRef] 
142. McCulloch, K.M.; Yamakawa, I.; Shifrin, D.A., Jr.; McConnell, R.E.; Foegeding, N.J.; Singh, P.K.; Mao, S.; Tyska, M.J.; Iverson, T.M. An alternative N-terminal fold of the intestine-specific annexin A13a induces dimerization and regulates membrane-binding. J. Biol. Chem. 2019, 294, 3454-3463. [CrossRef]

143. Oates, M.E.; Romero, P.; Ishida, T.; Ghalwash, M.; Mizianty, M.J.; Xue, B.; Dosztanyi, Z.; Uversky, V.N.; Obradovic, Z.; Kurgan, L.; et al. D(2)P(2): Database of disordered protein predictions. Nucleic Acids Res. 2013, 41, D508-D516. [CrossRef] [PubMed]

144. Dosztanyi, Z.; Csizmok, V.; Tompa, P.; Simon, I. IUPred: Web server for the prediction of intrinsically unstructured regions of proteins based on estimated energy content. Bioinformatics 2005, 21, 3433-3434. [CrossRef]

145. Ishida, T.; Kinoshita, K. PrDOS: Prediction of disordered protein regions from amino acid sequence. Nucleic Acids Res. 2007, 35, W460-W464. [CrossRef] [PubMed]

146. Walsh, I.; Martin, A.J.; Di Domenico, T.; Tosatto, S.C. ESpritz: Accurate and fast prediction of protein disorder. Bioinformatics 2012, 28, 503-509. [CrossRef] [PubMed]

147. Cheng, Y.; Oldfield, C.J.; Meng, J.; Romero, P.; Uversky, V.N.; Dunker, A.K. Mining alpha-helix-forming molecular recognition features with cross species sequence alignments. Biochemistry 2007, 46, 13468-13477. [CrossRef]

148. Oldfield, C.J.; Cheng, Y.; Cortese, M.S.; Romero, P.; Uversky, V.N.; Dunker, A.K. Coupled folding and binding with alpha-helix-forming molecular recognition elements. Biochemistry 2005, 44, 12454-12470. [CrossRef]

149. Meszaros, B.; Simon, I.; Dosztanyi, Z. Prediction of protein binding regions in disordered proteins. PLoS Comput. Biol. 2009, 5, e1000376. [CrossRef]

150. Dosztanyi, Z.; Meszaros, B.; Simon, I. ANCHOR: Web server for predicting protein binding regions in disordered proteins. Bioinformatics 2009, 25, 2745-2746. [CrossRef]

151. Arcuri, C.; Giambanco, I.; Bianchi, R.; Donato, R. Annexin V, annexin VI, S100A1 and S100B in developing and adult avian skeletal muscles. Neuroscience 2002, 109, 371-388. [CrossRef]

152. Garbuglia, M.; Verzini, M.; Donato, R. Annexin VI binds S100A1 and S100B and blocks the ability of S100A1 and S100B to inhibit desmin and GFAP assemblies into intermediate filaments. Cell Calcium 1998, 24, 177-191. [CrossRef]

153. Garbuglia, M.; Verzini, M.; Hofmann, A.; Huber, R.; Donato, R. S100A1 and S100B interactions with annexins. Biochim. Biophys. Acta 2000, 1498, 192-206. [CrossRef]

154. Semov, A.; Moreno, M.J.; Onichtchenko, A.; Abulrob, A.; Ball, M.; Ekiel, I.; Pietrzynski, G.; Stanimirovic, D.; Alakhov, V. Metastasis-associated protein S100A4 induces angiogenesis through interaction with annexin II and accelerated plasmin formation. J. Biol. Chem. 2005, 280, 20833-20841. [CrossRef] [PubMed]

155. Ecsedi, P.; Kiss, B.; Gogl, G.; Radnai, L.; Buday, L.; Koprivanacz, K.; Liliom, K.; Leveles, I.; Vertessy, B.; Jeszenoi, N.; et al. Regulation of the equilibrium between closed and open conformations of annexin A2 by N-terminal phosphorylation and S100A4-binding. Structure 2017, 25, 1195-1207.e5. [CrossRef] [PubMed]

156. Sopkova-de Oliveira Santos, J.; Oling, F.K.; Rety, S.; Brisson, A.; Smith, J.C.; Lewit-Bentley, A. S100 protein-annexin interactions: A model of the (Anx2-p11)(2) heterotetramer complex. Biochim. Biophys. Acta 2000, 1498, 181-191. [CrossRef]

157. Glenney, J.R., Jr.; Boudreau, M.; Galyean, R.; Hunter, T.; Tack, B. Association of the S-100-related calpactin I light chain with the NH2-terminal tail of the 36-kDa heavy chain. J. Biol. Chem. 1986, 261, 10485-10488. [PubMed]

158. Kube, E.; Becker, T.; Weber, K.; Gerke, V. Protein-protein interaction studied by site-directed mutagenesis. Characterization of the annexin II-binding site on p11, a member of the S100 protein family. J. Biol. Chem. 1992, 267, 14175-14182.

159. Jost, M.; Gerke, V. Mapping of a regulatory important site for protein kinase C phosphorylation in the N-terminal domain of annexin II. Biochim. Biophys. Acta 1996, 1313, 283-289. [CrossRef]

160. Johnsson, N.; Marriott, G.; Weber, K. P36, the major cytoplasmic substrate of src tyrosine protein kinase, binds to its p11 regulatory subunit via a short amino-terminal amphiphatic helix. EMBO J. 1988, 7, 2435-2442. [CrossRef]

161. Lambert, O.; Gerke, V.; Bader, M.F.; Porte, F.; Brisson, A. Structural analysis of junctions formed between lipid membranes and several annexins by cryo-electron microscopy. J. Mol. Biol. 1997, 272, 42-55. [CrossRef] 
162. Menke, M.; Ross, M.; Gerke, V.; Steinem, C. The molecular arrangement of membrane-bound annexin A2-S100A10 tetramer as revealed by scanning force microscopy. Chembiochem 2004, 5, 1003-1006. [CrossRef] [PubMed]

163. Cesarman-Maus, G.; Hajjar, K.A. Molecular mechanisms of fibrinolysis. Br. J. Haematol. 2005, 129, $307-321$. [CrossRef] [PubMed]

164. Girard, C.; Tinel, N.; Terrenoire, C.; Romey, G.; Lazdunski, M.; Borsotto, M. P11, an annexin II subunit, an auxiliary protein associated with the background K+ channel, TASK-1. EMBO J. 2002, 21, 4439-4448. [CrossRef] [PubMed]

165. Renigunta, V.; Yuan, H.; Zuzarte, M.; Rinne, S.; Koch, A.; Wischmeyer, E.; Schlichthorl, G.; Gao, Y.; Karschin, A.; Jacob, R.; et al. The retention factor $\mathrm{p} 11$ confers an endoplasmic reticulum-localization signal to the potassium channel TASK-1. Traffic 2006, 7, 168-181. [CrossRef]

166. Svenningsson, P.; Chergui, K.; Rachleff, I.; Flajolet, M.; Zhang, X.; El Yacoubi, M.; Vaugeois, J.M.; Nomikos, G.G.; Greengard, P. Alterations in 5-HT1B receptor function by p11 in depression-like states. Science 2006, 311, 77-80. [CrossRef]

167. Okuse, K.; Malik-Hall, M.; Baker, M.D.; Poon, W.Y.; Kong, H.; Chao, M.V.; Wood, J.N. Annexin II light chain regulates sensory neuron-specific sodium channel expression. Nature 2002, 417, 653-656. [CrossRef]

168. van de Graaf, S.F.; Hoenderop, J.G.; Gkika, D.; Lamers, D.; Prenen, J.; Rescher, U.; Gerke, V.; Staub, O.; Nilius, B.; Bindels, R.J. Functional expression of the epithelial Ca(2+) channels (TRPV5 and TRPV6) requires association of the S100A10-annexin 2 complex. EMBO J. 2003, 22, 1478-1487. [CrossRef]

169. Hirschhorn, R.R.; Aller, P.; Yuan, Z.A.; Gibson, C.W.; Baserga, R. Cell-cycle-specific cDNAs from mammalian cells temperature sensitive for growth. Proc. Natl. Acad. Sci. USA 1984, 81, 6004-6008. [CrossRef]

170. Tomas, A.; Moss, S.E. Calcium- and cell cycle-dependent association of annexin 11 with the nuclear envelope. J. Biol. Chem. 2003, 278, 20210-20216. [CrossRef]

171. Tokumitsu, H.; Mizutani, A.; Minami, H.; Kobayashi, R.; Hidaka, H. A calcyclin-associated protein is a newly identified member of the $\mathrm{Ca}^{2+} /$ phospholipid-binding proteins, annexin family. J. Biol. Chem. 1992, 267, 8919-8924. [PubMed]

172. Williams, L.H.; McClive, P.J.; Van Den Bergen, J.A.; Sinclair, A.H. Annexin XI co-localises with calcyclin in proliferating cells of the embryonic mouse testis. Dev. Dyn. 2005, 234, 432-437. [CrossRef]

173. Seemann, J.; Weber, K.; Gerke, V. Annexin I targets S100C to early endosomes. FEBS Lett. 1997, 413, $185-190$. [CrossRef]

174. Robinson, N.A.; Lapic, S.; Welter, J.F.; Eckert, R.L. S100A11, S100A10, annexin I, desmosomal proteins, small proline-rich proteins, plasminogen activator inhibitor-2, and involucrin are components of the cornified envelope of cultured human epidermal keratinocytes. J. Biol. Chem. 1997, 272, 12035-12046. [CrossRef] [PubMed]

175. Uversky, V.N. Intrinsic disorder-based protein interactions and their modulators. Curr. Pharm. Des. 2013, 19, 4191-4213. [CrossRef] [PubMed]

176. Jakob, U.; Kriwacki, R.; Uversky, V.N. Conditionally and transiently disordered proteins: Awakening cryptic disorder to regulate protein function. Chem. Rev. 2014, 114, 6779-6805. [CrossRef]

177. Uversky, V.N. P53 proteoforms and Intrinsic disorder: An illustration of the protein structure-function continuum concept. Int. J. Mol. Sci. 2016, 17, 1874. [CrossRef] [PubMed]

178. Smith, L.M.; Kelleher, N.L.; Consortium for Top Down, P. Proteoform: A single term describing protein complexity. Nat. Methods 2013, 10, 186-187. [CrossRef] [PubMed]

179. Schluter, H.; Apweiler, R.; Holzhutter, H.G.; Jungblut, P.R. Finding one's way in proteomics: A protein species nomenclature. Chem. Cent. J. 2009, 3, 11. [CrossRef]

180. Consortium, T.E.P. An integrated encyclopedia of DNA elements in the human genome. Nature 2012, 489, 57-74. [CrossRef]

181. Uhlen, M.; Bjorling, E.; Agaton, C.; Szigyarto, C.A.; Amini, B.; Andersen, E.; Andersson, A.C.; Angelidou, P.; Asplund, A.; Asplund, C.; et al. A human protein atlas for normal and cancer tissues based on antibody proteomics. Mol. Cell. Proteom. 2005, 4, 1920-1932. [CrossRef]

182. Farrah, T.; Deutsch, E.W.; Omenn, G.S.; Sun, Z.; Watts, J.D.; Yamamoto, T.; Shteynberg, D.; Harris, M.M.; Moritz, R.L. State of the human proteome in 2013 as viewed through peptideatlas: Comparing the kidney, urine, and plasma proteomes for the biology- and disease-driven human proteome project. J. Proteome Res. 2014, 13, 60-75. [CrossRef] [PubMed] 
183. Farrah, T.; Deutsch, E.W.; Hoopmann, M.R.; Hallows, J.L.; Sun, Z.; Huang, C.Y.; Moritz, R.L. The state of the human proteome in 2012 as viewed through peptideatlas. J. Proteome Res. 2013, 12, 162-171. [CrossRef] [PubMed]

184. Reddy, P.J.; Ray, S.; Srivastava, S. The quest of the human proteome and the missing proteins: Digging deeper. OMICS J. Integr. Biol. 2015, 19, 276-282. [CrossRef] [PubMed]

185. Kim, M.S.; Pinto, S.M.; Getnet, D.; Nirujogi, R.S.; Manda, S.S.; Chaerkady, R.; Madugundu, A.K.; Kelkar, D.S.; Isserlin, R.; Jain, S.; et al. A draft map of the human proteome. Nature 2014, 509, 575-581. [CrossRef]

186. Uversky, V.N. (Intrinsically disordered) splice variants in the proteome: Implications for novel drug discovery. Genes Genom. 2016, 38, 577-594. [CrossRef]

187. Darling, A.L.; Uversky, V.N. Intrinsic disorder and posttranslational modifications: The darker side of the biological dark matter. Front. Genet. 2018, 9, 158. [CrossRef]

188. Niklas, K.J.; Bondos, S.E.; Dunker, A.K.; Newman, S.A. Rethinking gene regulatory networks in light of alternative splicing, intrinsically disordered protein domains, and post-translational modifications. Front. Cell Dev. Biol. 2015, 3, 8. [CrossRef]

(C) 2020 by the authors. Licensee MDPI, Basel, Switzerland. This article is an open access article distributed under the terms and conditions of the Creative Commons Attribution (CC BY) license (http://creativecommons.org/licenses/by/4.0/). 